\title{
In vitro methods to support transporter evaluation in drug discovery and development
}

Brouwer, K L R ; Keppler, D ; Hoffmaster, K A ; Bow, D A J ; Cheng, Y ; Lai, Y ; Palm, J E ; Stieger, B ; Evers, R

\begin{abstract}
This white paper addresses current approaches and knowledge gaps concerning methods to assess the role of transport proteins in drug/metabolite disposition in humans. The discussion focuses on in vitro tools to address key questions in drug development, including vesicle- and cell-based systems. How these methods can be used to assess the liability of compounds for transporter-based drug-drug interactions (DDIs) in vivo is also explored. Existing challenges and approaches to examine the involvement of transporters in drug disposition are discussed.
\end{abstract}

DOI: https://doi.org/10.1038/clpt.2013.81

Posted at the Zurich Open Repository and Archive, University of Zurich ZORA URL: https://doi.org/10.5167/uzh-93549

Journal Article

Accepted Version

Originally published at:

Brouwer, K L R; Keppler, D; Hoffmaster, K A; Bow, D A J; Cheng, Y; Lai, Y; Palm, J E; Stieger, B; Evers, R (2013). In vitro methods to support transporter evaluation in drug discovery and development. Clinical Pharmacology and Therapeutics, 94(1):95-112.

DOI: https://doi.org/10.1038/clpt.2013.81 


\section{Clinical Pharmacology \&Therapeutics}

In Vitro Methods to Support Transporter Evaluation in Drug Discovery and Development

Kim L.R. Brouwer, Dietrich Keppler, Keith A. Hoffmaster, Daniel A.J. Bow, Yaofeng Cheng, Yurong Lai, Johan E. Palm, Bruno Stieger, Raymond Evers, (on behalf of the International Transporter Consortium)

Cite this article as: Kim L.R. Brouwer, Dietrich Keppler, Keith A. Hoffmaster, Daniel A.J. Bow, Yaofeng Cheng, Yurong Lai, Johan E. Palm, Bruno Stieger, Raymond Evers, (on behalf of the International Transporter Consortium), In Vitro Methods to Support Transporter Evaluation in Drug Discovery and Development, Clinical Pharmacology \& Therapeutics accepted article preview online 10 April 2013; doi:10.1038/clpt.2013.81

This is a PDF file of an unedited peer-reviewed manuscript that has been accepted for publication. NPG is providing this early version of the manuscript as a service to our customers. The manuscript will undergo copyediting, typesetting and a proof review before it is published in its final form. Please note that during the production process errors may be discovered which could affect the content, and all legal disclaimers apply.

Received 4 March 2013; accepted 5 April 2013; Accepted article preview online 10 April 2013 


\title{
In Vitro Methods to Support Transporter Evaluation in Drug Discovery and
}

\section{Development}

\author{
Kim L.R. Brouwer ${ }^{1 \star}$, Dietrich Keppler ${ }^{2}$, Keith A. Hoffmaster ${ }^{3}$, Daniel A.J. Bow ${ }^{4}$, Yaofeng \\ Cheng $^{5}$, Yurong Lai ${ }^{6}$, Johan E. Palm ${ }^{7}$, Bruno Stieger ${ }^{8}$, Raymond Evers ${ }^{9 *}$, \\ (on behalf of the International Transporter Consortium)
}

1 Division of Pharmacotherapy and Experimental Therapeutics, UNC Eshelman School of Pharmacy, The University of North Carolina at Chapel Hill, CB \#7569 Kerr Hall, Chapel Hill, NC 27599-7569, USA; Email: kbrouwer@unc.edu, Tel: +1-919-962-7030

2 German Cancer Research Center, D-69120 Heidelberg, Germany; Email: d.keppler@dkfz.de; Tel: +49-6221-422400

3 Novartis Institutes for BioMedical Research, Metabolism and Pharmacokinetics, USCA, 6001B-121, 250 Massachusetts Avenue, Cambridge, MA 02139, USA;

Email: keith.hoffmaster@novartis.com; Tel: +1-617-871-4353

4 Department of Drug Metabolism and Pharmacokinetics, AbbVie Inc., $1 \mathrm{~N}$. Waukegan Rd, North Chicago, IL, 60064, USA; Email: daniel.bow@abbvie.com; Tel: +1-847-937-2722

5 Pharmaceutical Candidate Optimization, Bristol-Myers Squibb, Princeton, NJ 08543, USA. Email: yaofeng.cheng@bms.com; Tel: +1-609-252-6096

6 Pharmaceutical Candidate Optimization, Bristol-Myers Squibb, Princeton, NJ 08543, USA. Email: yurong.lai@bms.com; Tel:+1-609-252-636

7 CVGI iMed DMPK, Innovative Medicines, AstraZeneca R\&D MöIndal, Pepparedsleden 1, SE43183 Mölndal, Sweden, Email: Johan.Palm@astrazeneca.com; Tel: +46 (0)317762677

8 Department of Clinical Pharmacology and Toxicology, University Hospital, 8091 Zurich, Switzerland, Email: bstieger@kpt.uzh.ch; Tel: +41-44-634-3169

9 Department of Pharmacokinetics, Pharmacodynamics and Drug Metabolism, Merck \& Co., Rahway, NJ, 07065, USA; Email: raymond evers@merck.com; Tel: +1-732-594-0427 


\section{${ }^{*}$ Address Correspondence to:}

*Kim L. R. Brouwer, Pharm.D., Ph.D.

Division of Pharmacotherapy and Experimental Therapeutics

UNC Eshelman School of Pharmacy

The University of North Carolina at Chapel Hill,

CB \#7569 Kerr Hall, Chapel Hill, NC 27599-7569, USA

Tel: +1-919-962-7030

FAX: +1-919-962-0644

Email: kbrouwer@unc.edu

*Dr Raymond Evers

Department of Pharmacokinetics, Pharmacodynamics and Drug Metabolism Merck \& Co, RY80-141

PO Box 2000

Rahway, NJ 07065

Tel: +1-732-594-0427

Email: raymond evers@merck.com;

Format: Review

Introduction: 75 words

Text: 7929 words (excluding introduction, references, tables, and figures) References: 74 (75 $\max )$

Figures and Tables: 3 Figures and 5 Tables

Running Title: In Vitro Approaches for Drug Transporter Evaluations

Number of Supplementary Files for Supporting Information online: 1 


\section{Footnotes:}

Abbreviations and notations used throughout the text, tables and figures are defined as follows: ABC: ATP-binding cassette; ADME: absorption, distribution, metabolism, and excretion; AUC: area under the curve; BCRP (ABCG2): breast cancer resistance protein; BEI: biliary excretion index; BSEP (ABCB11): bile salt export pump; CHO: Chinese Hamster Ovary cells; $\mathrm{CL}_{\text {bile, app: }}$ : apparent biliary excretion clearance from medium to bile; $\mathrm{CL}_{\text {bile, int }}$ : intrinsic biliary excretion clearance from cell to bile; $\mathrm{CL}_{\text {uptake }}$ : uptake clearance; DDI: drug-drug interaction; FRT: Flp Recombination Target; GST: glutathione S-transferase; HEK-293: human embryonic kidney cells; $I_{50}$ : concentration of inhibitor required to achieve $50 \%$ inhibition; $\mathrm{K}_{\mathrm{i}}$ : inhibition constant; $\mathrm{K}_{\mathrm{m}}$ : Michaelis-Menten constant; $\mathrm{K}_{\text {puu }}$ : hepatocyte-to-medium partition coefficient for unbound drug concentration; LLC-PK1: Porcine Kidney proximal tubule epithelial cells; MDCK or MDCKII: Madin-Darby canine kidney cells; MATE (SLC47A): multidrug and toxin extrusion protein; MDR1 P-gp (ABCB1): multi-drug resistance 1 P-glycoprotein; MRP (ABCC): multidrug resistance protein; NTCP (SLC10A1): $\mathrm{Na}^{+}$-taurocholate co-transporting polypeptide; OAT (SLC22A): organic anion transporter; OATP (SLCO): organic anion transporting polypeptide; OCT (SLC22A): organic cation transporter; $\mathrm{P}_{\text {app }}$ : apparent permeability; PBPK: physiologically based pharmacokinetic; SCH: sandwich-cultured hepatocytes; Sf9 or Sf21: Spodoptera frugiperda insect cells; UGT: UDP-glucuronosyltransferase; $V_{\text {max }}$ : maximum transport or metabolic rate 


\section{Introduction}

This whitepaper addresses current approaches and knowledge gaps concerning methods to assess the role of transport proteins in drug/metabolite disposition in humans. Discussion focuses on in vitro tools to address key questions in drug development, including vesicle and cell-based systems. How these methods can be used to assess the liability of compounds for transporter-based DDIs in vivo also is explored. Existing challenges and approaches to examine the involvement of transporters in drug disposition are discussed. 


\section{Why a Methods Whitepaper?}

In recent years, there has been increased recognition that drug transporters, in addition to drug metabolizing enzymes, play an important role in the absorption, distribution, and excretion of many drugs (1). The importance of drug transporters has been emphasized further by numerous examples where loss of function of transport proteins due to polymorphisms or drug-drug interactions (DDIs) has resulted in clinically significant changes in drug disposition, efficacy and even toxicity (2). Regulatory agencies, therefore, have come to expect that sponsors of new drug applications will conduct in vitro studies to assess the potential risk for transporter-mediated DDIs. Although general strategies on preferred experimental in vitro approaches have been provided in regulatory guidance documents, little is known about the predictive value of most systems, or whether results obtained from various laboratories are comparable.

In this whitepaper, transporter scientists from multiple pharmaceutical companies and academia representing the International Transporter Consortium provide an overview of the experimental systems currently employed to conduct in vitro transporter studies. Advantages and caveats of each system are highlighted, issues concerning data interpretation are discussed, and general comments about how in vitro data can be used to support drug discovery and development programs are provided. This whitepaper focuses on the seven transporters identified by the International Transporter Consortium as most clinically relevant (1), and transporters for which there is emerging evidence of importance (3). Where appropriate, discussion on other transporters has been included. Additional information about each of the transporters discussed in this whitepaper is detailed in the UCSF-FDA TransPortal (2).

A good example of the value of an in vitro test system to predict drug disposition in vivo is the application of polarized cell monolayers expressing ABCB1 (MDR1 P-gp). Using such cell systems, various laboratories have demonstrated that a good correlation can be established 
between the in vitro transcellular transport ratios in MDR1 or Mdr1a P-gp expressing cells and in vivo brain concentration ratios in $\mathrm{Mdr1}^{-/-} /$wild-type mice $(4,5)$. Another example is the application of cell lines transfected with OATP1B1 to qualitatively predict the potential of drug candidates to cause DDIs with statins (6). However, many questions remain about the integration of information generated from various assays, the optimal timing of such studies in the drug development process, and translation of in vitro data to in vivo. Furthermore, interpretation of assay results may be controversial in some cases, and assay limitations always must be considered. In vitro test systems must be selected based on the characteristics of the compound of interest, and multiple assay systems may be needed for some transporters. For instance, it is not feasible to study whether a compound with a poor apparent permeability $\left(\mathrm{P}_{\mathrm{app}}\right)$ will be a substrate for an efflux transporter in a whole cell system because diffusion into the cell may be rate-limiting; membrane vesicle or double transfected polarized cell monolayer systems would be more suitable to address this question Likewise, biliary clearance cannot be assessed directly in a vesicle-based transporter assay. A goal of this whitepaper is to begin to address which assay systems are most appropriate to answer specific transporter questions. This whitepaper focuses on vesicle systems, transfected cell lines and hepatocytes because these presently are the most commonly used tools in transporter research in the pharmaceutical industry. During our discussions, it became apparent that different approaches are used across laboratories and that reaching consensus was not always possible. In such cases, we have presented multiple assays that could be used to address the transporter-related issues or key questions.

Standardization of test systems, probe substrates and inhibitors has been implemented for CYP enzymes (7). This has allowed categorization of inhibitors as weak, moderate, or strong, which is something that currently is not available for transporters due to the lack of selective probe substrates and inhibitors both in vitro and in vivo. At present, efforts to harmonize in vitro transporter assay formats, probe substrates and inhibitors between 
laboratories have been very limited. The need for investment in this area has been highlighted based on recent work comparing inhibition data for MDR1 P-gp across twenty-three laboratories with sixteen inhibitors in various expression systems (J. Bentz, H. Ellens and C. Lee, personal communication). The results from this comparison demonstrated a wide difference in $\mathrm{IC}_{50}$ values, depending on the inhibitor tested. This whitepaper provides recommendations regarding which systems should be used to address specific transporter-related questions in the drug development process. References to standard protocols and methodological details are provided.

\section{Vesicle-based Transporter Assays and Uptake Studies in Recombinant Cell Lines}

An important point of consideration before initiating transporter experiments is which assay system is most appropriate. Efflux transport of drugs and endogenous compounds from cells often is mediated by ATP-dependent unidirectional pumps, as exemplified by the uphill transport from hepatocytes into bile by the $A B C$ transporters $A B C B 11$ (BSEP), $A B C C 2$ (MRP2), $A B C B 1$ (MDR1 P-gp) or ABCG2 (BCRP). Since these transporters are expressed in the canalicular (apical) membrane of the hepatocyte, intact cell systems expressing only these transporters may not be an appropriate system in the absence of a relevant uptake transport mechanism. Transport by these proteins can be studied using inside-out-oriented membrane vesicles, achieved by demonstration of ATP-dependent transport of a substrate into the vesicle, as shown originally with vesicles produced from erythrocytes (Figure 1) (8). As there is direct access of the substrates to the internal side of the transporter in the plasma membrane, insideout membrane vesicles allow one to obtain information on substrate specificity, co-factor requirements, and substrate affinity. 


\section{Preparation of Vesicles}

Cell lines commonly used for the isolation of membrane vesicles containing recombinant human ABC transporters include Spodoptera frugiperda insect cells (Sf9 or Sf21) infected with a baculovirus containing a cDNA encoding an ABC transporter, and cDNA-transfected mammalian cell lines such as HeLa, V79 hamster, human embryonic kidney (HEK-293), and Madin-Darby canine kidney (referred to herein as MDCK although other clones including MDCKII are used). Endogenous background activity of ATP-dependent transport is detectable in all of these cell lines and requires control measurements with vesicles from non-transfected cells (9). Vesicles also can be isolated from tissues (e.g. kidney or liver) allowing for the simultaneous investigation of several endogenous $A B C$ transporters in inside-out-oriented apical or basolateral membrane vesicles (10). An important consideration in this approach is that cross-contamination with vesicles from the opposite membrane domain needs to be taken into account since different transporters in the two membrane domains may share the compound of interest as a substrate and have different transport capacities.

Several groups have described the preparation of vesicles from transfected mammalian cells $(11,12)$. The most critical step for vesicle isolation is the homogenization of the starting material. The method of homogenization needs to be adjusted based on the starting material, and it is important to keep the conditions of homogenization constant $(10,12,13)$. For isolated cells, a very tight (small clearance between pestle and cylinder wall) homogenizer at a high speed and a hypotonic buffer will yield vesicles suitable for transport experiments (12). The strength of the homogenization may need to be balanced against the purity of the vesicle fraction necessary for the planned experiment. If purity of vesicles is critical, they should be characterized fully as described previously $(10,13)$,

Because vesicles are not living cells, compounds that may be cytotoxic in other assays will not confound interpretation of experimental results from vesicle studies. Additionaly, vesicle studies are ideally suited to investigate the role of $\mathrm{pH}$ or $\mathrm{pH}$ gradients, cation and anion 
dependency as well as driving forces for transport systems. Importantly, as vesicle transport experiments require rather small amounts of vesicles (e.g. 50 to $70 \mu \mathrm{g}$ protein), it is feasible to conduct high-throughput assays and obtain a significantly larger number of data points in a short time period than from a similar amount of intact cells. In addition, isolated membrane vesicles can be stored at $-80^{\circ} \mathrm{C}$ for a long period of time and can be thawed easily for use when needed, although repeat freeze-thaw cycles may compromise assay performance. Now, membrane vesicles containing the commonly used $A B C$ transporters are commercially available, allowing data comparison among different labs.

\section{Study Design Considerations for Vesicle-based Transporter Assays}

Co-substrate and co-factor requirements of $A B C$ transporters should be taken into consideration in designing experiments. For instance, reduced glutathione, which is present in living cells at millimolar concentrations, is required for transport of some substrates by MRP1 (14), MRP2 (15), and MRP4 (16); in some cases, glutathione transport was associated with drug transport $(14,17)$. Accordingly, these assays may require an additional control with transport in the presence of $5 \mathrm{mM} \mathrm{GSH}$ or S-methyl-glutathione. Inhibition studies for transporters showing cooperativity need to be performed over a range of substrate and inhibitor concentrations (18). It is important to realize that inhibition studies are not suitable to test whether or not a compound is a substrate. This approach is sometimes chosen if a new substrate is not available in radiolabeled form or LC-MS-MS analysis is not available. There are ample examples that some inhibitors are not actually transported by the carriers studied (19, 20).

The measured concentration of substrates and inhibitors in a vesicle suspension represents the unbound concentration, which is defined as the product of the unbound fraction and the total drug concentration. Concentrations selected for investigation in vesicle systems 
should bracket the expected unbound concentration at the site of transport. Unbound concentrations in plasma may not necessarily be equivalent to unbound cellular concentrations, as discussed in detail by Chu et al. (see this issue). If albumin (or another binding protein) is added to the vesicle incubation buffer, as is occasionally done for poorly water-soluble substrates or inhibitors, the unbound concentration must be experimentally determined. Protein binding can be impacted by the ionic strength of the buffer, thus affecting kinetic parameters that depend on the unbound substrate concentration (21). Vesicular systems are well suited to determine kinetic parameters for drug transport and to obtain mechanistic insight regarding DDIs. Further work is needed to determine whether data generated in vesicle-based systems is useful to predict overall drug disposition and susceptibility to DDIs when incorporated into pharmacokinetic models. Modeling approaches that account for the complexity of the in vivo system, including the contribution of individual uptake and efflux transporters, may increase the overall value of data generated in vesicular systems.

Passive permeation of substrates into the vesicles has to be taken into account. For ABC transporters, ATP can be replaced by 5'-AMP or by a non-hydrolyzable ATP analog such as AMP-PCP (see Figure 2). Additionally, binding of substrates to vesicle membranes may confound kinetic parameters and inhibition studies. Binding potentially can be assessed by performing initial uptake experiments with increasing incubation time, followed by backextrapolation of the initial uptake rates to zero incubation time. The intercept with the ordinate (if significantly different from zero) represents binding to the outer leaflet of the vesicles. Total binding (to the inner and outer leaflet of vesicles) can be assessed by determination of the osmotically sensitive intra-vesicular space for the substrate under investigation. Such experiments must be performed under equilibrium conditions, but with identical uptake conditions as used for initial uptake rates. The addition of non-specific binding proteins (e.g. albumin) to the ice-cold stop-solution can reduce the binding of hydrophobic substrates. If the binding component is large, an initial test of substrate binding to the filter is warranted. Such a 
problem can be (in part) solved by using different filter materials or by pre-incubating filters with a high concentration of unlabeled substrate. In some cases, addition of an excess of unlabeled substrate to the stop-solution may be useful. Filtration of the vesicles through a gel matrix by centrifugation may serve as another useful approach, as illustrated in Figure 1.

Methods for quenching the transport reaction with stop-solution and filtering the vesicles both must be considered carefully. In order to efficiently terminate the uptake into vesicles, dilution of the incubation reaction 30 - to 50 -fold with an ice-cold stop-buffer is required. While this condition is sufficient to terminate uptake of transported substrates, it does not prevent efflux of substrates from the vesicle lumen back into the buffer (22). Therefore, the transfer of the vesicle suspension into the filtration device and the filtration step must be quick, and follow a consistent timeline to achieve low standard deviations and reproducibility of data.

In determining whether a compound is a substrate for an $A B C$ transporter in vesicle uptake studies, it should be realized that false-negative results can be obtained for highly lipophilic compounds due to high non-specific binding to lipid membranes or extensive diffusion. For inhibition studies, selection of probe substrates is critical for the generation of meaningful data if a vesicular system is used to determine $I_{50}$ values. Optimal substrates should give significantly higher values than blanks, have a low apparent permeability, and exhibit low nonspecific binding to filters and vesicles. Ideally, probe substrates that will be selected as victim drugs in clinical DDI studies should be used, but this may not always be possible for technical reasons. In such cases, validation data need to be generated with known inhibitors to demonstrate that the $\mathrm{IC}_{50}$ or $\mathrm{K}_{\mathrm{i}}$ values measured are predictive for clinical DDIs that have been ascribed to inhibition of the transporter of interest. Recommended substrates and inhibitors of ATP-dependent transport into inside-out membrane vesicles are given in Table 1 for the following ABC transporters: ABCB1 (MDR1 P-gp), ABCG2 (BCRP), ABCC1 (MRP1), ABCC2 (MRP2), ABCC3 (MRP3), ABCC4 (MRP4), and ABCB11 (BSEP). These substrates and inhibitors have been used successfully in the authors' laboratories. At present, no general 
recommendations can be provided for preferred substrates because systematic comparisons between laboratories have not been conducted.

\section{Generation of Recombinant Cell Lines}

Full length cDNAs encoding a transporter of interest can be cloned from cDNA libraries using High Fidelity DNA polymerase and sequence specific primers, or in many cases can be obtained commercially. Native stop codons should be included in order to prevent incorporation of amino acids not present in the native protein. CDNAs must be sequenced for accuracy prior to the generation of expression systems, and mutations should be corrected by site directed mutagenesis.

The host mammalian cell lines commonly used for the expression of transporters include Human Embryonic Kidney (HEK293) cells, Porcine Kidney Epithelial cells (LLC-PK1), MadinDarby Canine Kidney (MDCK) cells and Chinese Hamster Ovary $(\mathrm{CHO})$ cells. Among these cells, HEK293 and CHO cells are used commonly for expressing uptake transporters, as they demonstrate low endogenous transporter activity and are easy to maintain. Several laboratories also use MDCK cells for the expression of uptake transporters. MDCK and LLC-PK1 cells can form tight polarized cell monolayers, and are used commonly for the expression of efflux transporters. Oocytes from Xenopus laevis have been used historically for expression cloning of transporters and to characterize transporter function and mechanism of transport. Although oocytes are an available tool, some data suggest that transporter kinetic parameters determined using oocytes are not always comparable to those generated in mammalian cells (23). Guidance from regulatory agencies indicates that transport studies should be conducted in an in vitro system where the human in vivo transporter function is preserved (www.fda.gov; www.ema.europa.eu). 
Plasmids with transporter cDNA can be introduced into the host cell line either chemically, physically, or by retroviral transduction. Electroporation is a popular method for physical transfection and is very efficient for $\mathrm{CHO}$ cells. Transporter cDNA can be transiently transfected into the host cells, but this method is less preferred as transporter expression levels can be quite variable. For stable transfection, a chemical resistance gene, usually conferring resistance to geneticin or hygromycin, is co-constructed into the plasmid vector allowing host cells to constitutively produce the protein of interest under selection pressure. To improve the stable transfection efficiency, and to allow integration of a cDNA in a fixed locus, systems such as the Flp-In system have been developed, which integrates the cDNA of interest into the genome via Flp recombinase-mediated specific DNA recombination (24). Genetically modified HEK, CHO and MDCKII cells with an Flp Recombination Target (FRT) site and the matching expressing vector are commercially available or can be custom made. Successful transfection of the transporter should be confirmed by measuring transporter mRNA, and protein production and localization by Western blotting and immunocytochemistry, respectively. Significant transport of a probe substrate and inhibition by a prototypical inhibitor (Table 2), serves as an indicator of the proper function of the transporter in the transfected cell line.

\section{Study Design Considerations for Uptake Studies in Recombinant Cell Lines}

For substrate determination, the compound of interest is incubated with cells expressing the uptake transporter, usually for $<10 \mathrm{~min}$ unless an energy source such as glucose is provided. Accumulation of the compound must be significantly higher (generally more than 2fold) in transporter expressing than in non-transfected parental (wild-type) cells, or cells transfected with empty vector (mock-transfected), in order to conclude that a compound is a substrate. Uptake can be confirmed by comparing the uptake in the absence and presence of an established inhibitor (Table 2). Prior to conducting kinetic studies, uptake should be conducted at various time points to determine the range of linear uptake. The recommended 
approach for accurate determination of kinetic parameters $\left(\mathrm{V}_{\max }\right.$ and $\left.\mathrm{K}_{\mathrm{m}}\right)$ is described below (see Data Analysis). A parallel study in parental cells is recommended to determine background transport.

To determine the inhibitory effect of a test compound, the intracellular accumulation of a probe substrate (Table 2) should be measured in the presence and absence of increasing concentrations of the compound of interest. Consideration should be given to the incubation time (pre-incubation and/or co-incubation) with the inhibitor depending on the permeability of the compound and whether it is a transporter substrate. In some cases, trans- or time-dependent inhibition could occur or the inhibitor may be metabolized. For kinetic analysis, inhibition should be determined at initial uptake rates of the probe substrate. The same considerations outlined for data obtained in membrane vesicles also apply to intact cell systems. Due to the complexity of transporter characteristics (e.g. overlap in substrate and inhibitor specificity across transporters, and the presence of multiple drug binding sites for some transporters), caution must be taken in extrapolating in vitro kinetic data to in vivo.

For both uptake and inhibition studies, compound solubility should be taken into account in designing experiments. Organic solvents, such as DMSO, can be added to increase compound solubility, but the maximal concentration at which solvents are tolerated by the cell system (usually $<1 \%$ ) without impacting cell viability or transporter function should be determined. For compounds with low solubility, albumin or other excipients can be added to the incubation buffer, but the unbound concentration of the compound will need to be determined, as data interpretation otherwise will be complicated.

Consistent procedures should be followed in conducting transport studies to minimize experimental variability, such as starting cell seeding numbers, growing period of cells and conditions, dosing solution preparation, and incubation time. Typically, experiments are conducted at $37^{\circ} \mathrm{C}$. Processing of the cells depends on the method used for compound detection, which may include LC-MS/MS analysis or scintillation counting. The rate of uptake 
commonly is normalized to protein concentration $(\mathrm{mg})$ to allow accurate determination of transporter specific uptake compared to uptake in wild-type (or mock-transfected cells). The inclusion of positive and negative controls is critical for accurate interpretation of the generated data. .

\section{Data Analysis for Vesicle-Based Transporter Assays and Uptake Studies in Recombinant}

\section{Cell Lines}

The general rules outlined below apply both to transport experiments with cellular systems and to transport experiments with vesicles. The time course of uptake may deviate quickly from linearity due to rapid accumulation of substrate inside vesicles or cell lines. Therefore, selection of early and appropriate time points in the initial linear phase (i.e. initial uptake rates) is critical for accurate determination of kinetic parameters. For example, the ATPdependent transport of the glutathione $S$-conjugate $\mathrm{LTC}_{4}$ into MRP1-containing membrane vesicles is shown in Figure 2. Linearity of the system with respect to protein amount or cell number also needs to be considered in the experimental design, and binding to the membrane should be taken into account. In the case of vesicles, the rate of ATP-dependent transport of various substrates is calculated on the basis of vesicle protein (e.g. given in $\mathrm{mg}$ ) and yields only relative values for different substrates within a membrane preparation. Absolute values are obtained for affinity ( $\mathrm{K}_{\mathrm{m}}$ value) and inhibition constants $\left(\mathrm{K}_{\mathrm{i}}\right.$ and $\mathrm{IC}_{50}$ values), and are not affected by the percentage of inside-out-vesicles, assuming that transport is ATP-dependent. To best define the kinetic parameters, a zero concentration control (blank) and at least seven substrate concentrations should be selected that cover the linear and non-linear range of transport; the highest concentration evaluated should be at least $90 \%$ of the maximal transport velocity (e.g. $\mathrm{V}_{\max }$ ). The standard procedure for data analysis is to fit a Michaelis-Menten equation (Table 3, eq. 1) to the data. A linear component can be added to the Michaelis-Menten equation to account for passive diffusion, if applicable (Table 3, eq. 1). Non-linear regression analysis of the 
non-transformed data is the preferred method of data analysis, although linear transformation of data can help identify the involvement of multiple transporters or multiple binding sites. For example, Eadie-Hofstee or Hanes-Woolf plots readily provide information on the presence and activity of more than one transporter. The use of Hanes-Woolf or Hill plots should be considered when complex transporter biology (e.g., cooperativity) is suggested (18). Assessment of drug interaction potential often involves determination of $\mathrm{IC}_{50}$ values using a probe substrate at a concentration well below the $\mathrm{K}_{\mathrm{m}}$ and a range of purported inhibitor concentrations relevant to expected or known clinical exposures, with consideration for total and unbound maximal concentrations at the relevant site(s) of inhibition (e.g., plasma, intracellular). Important considerations in the determination of $\mathrm{IC}_{50}$ values include:

(i) The $\mathrm{IC}_{50}$ value depends on the substrate concentration (in contrast to the $\mathrm{K}_{\mathrm{i}}$ value, which gives the affinity of the inhibitor to the probe substrate binding site). This is relevant if $\mathrm{IC}_{50}$ values are used for in vivo extrapolations.

(ii) $\quad \mathrm{IC}_{50}$ values will approach $\mathrm{K}_{\mathrm{i}}$ if a substrate concentration far below the $\mathrm{Km}$ is used (see points (iv) and (v) below).

(iii) Different mathematical models may be used to estimate $\mathrm{IC}_{50}$ values, which may affect the comparison of $I C_{50}$ values between laboratories.

(iv) $\mathrm{IC}_{50}$ values do not provide information on the type of inhibition.

(v) Study designs should utilize probe substrate concentrations within 2-fold of the $\mathrm{K}_{\mathrm{m}}$ value. If the substrate concentration is $>50 \%$ of the $\mathrm{K}_{\mathrm{m}}$ value, calculation of $\mathrm{K}_{\mathrm{i}}$ values with the Cheng-Prusoff equation (Table 3, eq. 2) may yield incorrect estimates of the true value. (At low probe substrate concentrations, the accuracy of the data will be affected strongly by binding problems).

(vi) The Cheng-Prusoff equation assumes that the inhibition is competitive in nature.

Dixon plot analysis is the method of choice for detailed analysis of inhibition data including determination of the $\mathrm{K}_{\mathrm{i}}$ value; this approach provides information on the type of inhibition 
(competitive versus non- or uncompetitive). The $\mathrm{K}_{\mathrm{i}}$ value is a more robust parameter that should be comparable across laboratories for a given set of inhibition data. The use of proper controls and validated assays coupled with $\mathrm{IC}_{50}$ value determination may be acceptable to guide decision making with regard to DDI potential. Similar considerations also apply to the analysis of cell-based systems expressing uptake transporters.

\section{Cell-based Transporter Assays}

\section{Bidirectional Transport in Recombinant Cell Lines}

Bidirectional transport assays in polarized cell monolayers (e.g. LLC-PK1, MDCK or Caco-2) are used to study efflux transporters or the interplay between uptake and efflux transporters (Figure 3.A). Assays are performed with cell lines stably or transiently transfected with cDNAs encoding the transporter(s) of interest, as discussed above, and cells are seeded on a permeable membrane support to form a tight cell monolayer. In most cell lines established thus far, uptake transporters are localized in the basolateral membrane (e.g., OATP1B1, OATP1B3, OATP2B1, OCT1, or OCT2), and efflux transporters in the apical membrane (e.g., MDR1 P-gp, BCRP, MRP2, or MATE; (25-27)).

In a typical bidirectional transport experiment to establish transporter-mediated uptake/efflux, the test compound is added to the apical (A) compartment, with buffer in the basolateral (B) compartment (A-B transport), and in parallel wells, test compound is added to the basolateral compartment, with buffer in the apical compartment (B-A transport). Acceptance criteria for the tightness of the cell monolayer need to be established. Typically, this is assessed by measuring the paracellular flux of a low permeability compound (e.g. inulin, mannitol, or lucifer yellow). Experiments can be conducted as a time course by taking samples from both compartments at various time points, but in most cases transport is linear over time, and therefore, samples can be taken at one fixed time point (typically at $\mathrm{t}=1-4 \mathrm{hr}(28)$ ). For each 
direction of transport, the apparent permeability $\left(P_{\text {app }}\right)$ is calculated (Table 3 , eq. 3 ), and data are reported as the $\mathrm{P}_{\text {app }} \mathrm{B}-\mathrm{A} / \mathrm{A}-\mathrm{B}$ ratio.

Theoretically, the B-A/A-B in the control cell line will be at unity, but this is not always the case due to the presence of endogenous transporter activity $(29,30)$. The cut-off for significant transport (with no transport in the control cell monolayers) is typically at a B-A/A-B ratio of 2 , but depends on the sensitivity and reproducibility of the assay system. Accuracy of the transport ratio also depends on the mass balance, which is defined as the total drug recovered in the receiver and donor solutions at the end of the experiment relative to the amount of drug added at $t=0$. Mass balance is important to consider for compounds with low solubility, high nonspecific binding, or possible metabolism. In such cases, the assay will yield data that are difficult to interpret. A typical cut-off for mass balance is $>70 \%$.

Bidirectional transport assays are a sensitive method to determine transport of test compounds because only transport of compound that is fluxed through the cell monolayer (either para- or trans-cellularly) is measured and therefore, transport measurements are less confounded by compound binding to cell membranes (as in direct cell uptake or vesicular uptake experiments). However, there are limitations to this system: (i) Compounds can be identified as non-substrates due to saturation of efflux transport activity. Based on experience in multiple drug discovery programs, this usually can be avoided for MDR1 P-gp by choosing drug concentrations $\leq 1 \mu \mathrm{M}$ (RE, unpublished data). (ii) For cells expressing only apical efflux transporters, transport will be limited by the diffusion rate across the basolateral membrane or be dependent on the presence of endogenous uptake transporter(s). Thus, for compounds with low permeability, the Papp B-A/A-B ratio may be underestimated. In cases where a compound is known to be a substrate for an uptake transporter, this problem can be overcome by the application of double transfected cell lines. (iii) Quantitative interpretation of data obtained is difficult, although correlating B-A/A-B ratios to the capacity of test compounds to cross the blood-brain-barrier has been successful $(4,5)$. Recent studies have suggested that endogenous 
transporters present in polarized cell monolayers may complicate determination of kinetic parameters (e.g., deriving transport kinetics via P-gp in MDCK cells). Various complex modeling approaches to derive kinetic data based on bidirectional transport experiments have been published and are discussed by Zamek-Gliszczynski et al. (see this issue).

For known MDR1 P-gp substrates, bidirectional transport assays are one of the recommended methods to assess inhibition of transport by potential perpetrator drugs (1). In these experiments, cell monolayers are incubated with various concentrations of test compound in both the apical and basolateral compartment, and the effect on the bidirectional transport of a probe substrate is measured. If studies are conducted to assess the propensity of a test compound to be a perpetrator of MDR1 P-gp in the clinic, use a clinically relevant drug as the substrate is recommended because MDR1 P-gp is known to contain multiple drug binding sites (31), and inhibition may be substrate dependent. $I C_{50}$ values can be calculated by various methods, but currently there is no consensus on the most optimal approach $(32,33)$. An extensive evaluation of $\mathrm{IC}_{50}$ values across a range of laboratories with various $\mathrm{P}$-gp inhibitors and digoxin as the probe substrate has revealed high inter-lab variability, even if cell lines from the same origin and identical $\mathrm{IC}_{50}$ calculation methods were employed (J. Bentz, $\mathrm{H}$. Ellens and C. Lee, personal communication). Thus, it is recommended that assay systems are validated within each lab with a range of known MDR1 P-gp inhibitors.

Caco-2 cell monolayers can be used as an in vitro screening tool to predict oral absorption in humans as Caco-2 cells are derived from human colon carcinoma and resemble the characteristics of human small intestinal enterocytes when grown on permeable filters, form tight junctions, microvilli, and produce several human enzymes and transporters (34). Conducting experiments with Caco-2 cells is similar to other bidirectional transport assays. A detailed description of cell culture, experimental procedures and data analysis can be found in Hubatsch et al. (35). A correlation has been established using Caco-2 cells between transcellular and para-cellular flux for a number of drugs, and transporter-mediated drug absorption 
(36). Limitations of Caco-2 assays include the long differentiation time, and the significant variability in permeability and transporter expression levels among laboratories. Thus, markers for permeability (e.g., inulin and propanolol) should be included as controls in each experiment, and the expression levels of transporters should be determined by each individual laboratory. Of note, it has been established that MDCK monolayers also can be used as model systems to predict oral absorption of drugs for non-transporter substrates $(37,38)$.

\section{Suspended Hepatocytes to Characterize Hepatic Uptake}

Freshly isolated or cryopreserved hepatocytes have been widely accepted as a holistic model to identify substrates for hepatic uptake transporters and to predict hepatic clearance. Fresh hepatocytes traditionally are isolated by collagenase perfusion of livers from rat or human donors as described previously (39). The hepatocyte suspension is prepared in medium (e.g., William's E medium) or buffer (e.g., Hanks Balanced Salt Solution) without phenol red, and aliquots of hepatocytes are then dispensed into a test tube and kept on ice until the start of the experiment. Suspended hepatocytes should be used within a few hours because cell viability decreases over time. After a 10 -minute pre-incubation at $37^{\circ} \mathrm{C}$, active uptake is initiated by the addition of an equal volume of medium or buffer containing test compounds with and without known transporter inhibitors. At designated time points, the incubation is terminated by rapidly separating the cells from the medium or buffer using a rapid filtration approach with a cell harvester, direct centrifugation, or centrifugation through a layer of mineral oil $(6,40) .\left[{ }^{14} \mathrm{C}\right] \mathrm{Inulin}$ can be used to correct for adherent fluid volume. The cells are lysed and subjected to analysis by LC-MS/MS or scintillation counting. Active hepatic uptake is estimated from the initial uptake phase (Table 3, eq. 4), which may occur as quickly as $0.5 \mathrm{~min}$ (e.g. taurocholate has rapid uptake 0.5 to 1.5 minutes). Initial rates of hepatic uptake are estimated by linear or dynamic regression analysis (41). Uptake measured beyond the initial range may be confounded by both uptake and efflux processes (30). The percentage of active uptake can be determined from 
the slope of the initial uptake phase compared to the slope of uptake with known inhibitors, intended to represent only the passive component of uptake (Table 3, eq. 5). There is some debate among experts about the best approach to assess the contribution of passive diffusion to overall uptake. The classic method involved measurement of uptake in suspended hepatocytes at $4^{\circ} \mathrm{C}(40)$, but this approach is confounded by the fact that membrane fluidity is also temperature sensitive. Uptake by the sodium-dependent taurocholate co-transporting polypeptide (NTCP) can be determined using an uptake buffer with and without sodium $(\mathrm{NaCl}$ and $\mathrm{NaHCO}_{3}$ replaced with choline $\mathrm{Cl}$ and choline bicarbonate, respectively) (42). Replacing extracellular $\mathrm{NaCl}$ with $\mathrm{KCl}$ for these studies may alter cell homeostasis, impair cell viability, and should be avoided (43). To reduce the labor associated with the isolation of fresh hepatocytes, cells also can be cryopreserved if they are not used immediately post isolation because the majority of hepatic drug transporters appear to be preserved (44). Suspended hepatocytes often are used to determine the role of transporters in hepatic uptake because plated hepatocytes exhibit decreased transporter function after just a few hours in culture (45). Inter-individual differences in protein expression and/or genetic polymorphisms can be overcome by pooling hepatocytes from multiple donors $(46,47)$.

Hepatocyte uptake studies are useful to assess the contribution of passive vs. active processes to initial uptake in the species of interest. Data may be confounded by efflux from hepatoyctes if studies are not conducted within the linear range of initial uptake. Nonspecific binding of some compounds may be significant and must be accounted for during data analysis. Due to the lack of specific inhibitors and substrates, it may be challenging to determine which individual isoforms of specific uptake transporters are involved in uptake of compounds. Suspended hepatocytes are not suitable for measuring canalicular efflux because proteins on the canalicular membrane internalize during hepatocyte isolation (48). Recently, it was found that in cryopreserved hepatocytes the passive permeability of the OATP substrate pitavastatin varied significantly among donors although the absolute amount of OATP protein was relatively 
constant; membrane leakage may contribute to this observation, which would complicate the interpretation of uptake data (49). Further investigations are needed to confirm whether this finding applies to other substrates when cryopreserved hepatocytes are used for uptake studies. As an alternative to measuring compound uptake, compound disappearance from the medium has been proposed as a substitute for measuring direct uptake (50). However, this method does not allow discrimination between adsorption of compound to incubation plates or uptake into cells, and precludes kinetic analysis of the data (an important assumption of the MichaelisMenten equation is that concentrations are constant over the time interval of measurement).

\section{Sandwich-Cultured Hepatocytes (SCH) to Characterize Hepatic Uptake and Biliary}

\section{Excretion}

The use of sandwich-cultured hepatocytes $(\mathrm{SCH})$, as shown in Figure 3B, has become a valuable in vitro tool in drug discovery and development. $\mathrm{SCH}$ retain more in vivo-like properties, including the formation of intact canalicular networks and polarized excretory function (51). This system has been established successfully for multiple species including rat and human hepatocytes. Freshly isolated or cryopreserved hepatocytes are cultured on collagen coated plates overlaid with collagen or Matrigel ${ }^{\mathrm{TM}}$ (BD Bioscience) for a period of 4 days (rat $\mathrm{SCH}$ ) or 6-7 days (human $\mathrm{SCH}$ ), depending on the species and culture conditions, to allow time for hepatocyte polarization and re-establishment of canalicular networks. Hepatic uptake in $\mathrm{SCH}$ is initiated by the addition of HBSS containing substrates, with or without inhibitor. The hepatic uptake of test compounds is estimated from the initial uptake phase (typically less than $2 \mathrm{~min}$ ); the initial uptake rate in $\mathrm{SCH}$ is estimated by linear or dynamic regression. The uptake clearance $\left(\mathrm{Cl}_{\text {uptake }}\right)$ is calculated according to Table 3, Eq. 4. (52). Incubating $\mathrm{SCH}$ in calcium/magnesium-free buffer disrupts the tight junctions that form the bile canalicular network (53). Using this approach, the biliary excretion of compounds can be determined by comparison of accumulation in normal buffer (representing cell + bile canalicular 
network content) vs. accumulation in calcium/magnesium-free buffer (representing cellular accumulation) (B-CLEAR ${ }^{\circledR}$ technology) $(53,54)$. Data are corrected for any nonspecific binding of compound to the collagen or Matrige ${ }^{\mathrm{TM}}$ plates.

The biliary excretion index (BEI), which represents the fraction of accumulated compound that resides in the bile compartments, is calculated based on the Accumulation $_{\text {std, }}$

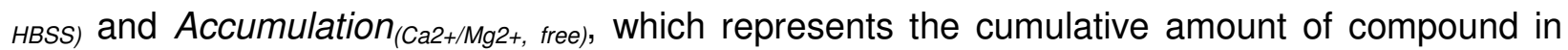
$\mathrm{SCH}$ in the presence and absence of $\mathrm{Ca}^{2+} / \mathrm{Mg}^{2+}$, respectively (Table 3, Eq. 6) (53). The apparent in vitro biliary clearance $\left(C L_{\text {bile,app }}\right)$ is calculated based on the medium AUC, and defines the apparent biliary excretion clearance from medium to bile (Table 3, Eq. 7) (53). The $C L_{\text {bile,app }}$ and BEI typically are determined at $10 \mathrm{~min}$, but the optimal time is compound-specific, which depends on the time-course of accumulation in hepatocytes. Intracellular concentrations can be estimated from the mass of compound that accumulates in hepatocytes normalized for hepatocyte volume (55), or by using $\mathrm{K}_{\mathrm{p}, \mathrm{uu}}$ obtained from a model where active uptake processes are involved (Chu et al., see this issue). The intrinsic biliary efflux clearance $\left(C L_{\text {bile,int }}\right)$, which represents the biliary efflux clearance from hepatocyte to bile, can be calculated based on the intracellular AUC (Table 3, Eq. 8).

The BEl obtained from $\mathrm{SCH}$ is a qualitative index of biliary excretion (56). BEI and biliary clearance values should be compared to a positive control, such as the model bile acid taurocholate, which undergoes rapid hepatic uptake and extensive biliary excretion. Hepatic uptake and biliary clearance values can be scaled to per kilogram of body weight, depending on the species, and used as input for PBPK models to predict the pharmacokinetics of test compounds $(57,58)$. In vitro biliary clearance values generated for compounds in SCH and scaled biliary clearance values correlate well with in vivo biliary clearance data in rats $(53,59$, $60)$ and humans $(61,62)$.

A caveat of the $\mathrm{SCH}$ system is that maintaining cells in $\mathrm{Ca}^{2+}$-free medium for prolonged periods of time (>20-30 min) causes cell toxicity (51). Thus, compounds with a low transport 
clearance require a modified experimental design to accurately estimate cellular accumulation and biliary excretion. The maintenance of metabolizing enzymes and transporter expression in human $\mathrm{SCH}$ is dependent on culture conditions and has been characterized (51). Inducers and inhibitors can be employed to assess DDI potential of drugs and generated metabolites in $\mathrm{SCH}$, which contain functional trafficking and regulatory machinery along with hepatocyte-specific endogenous compounds $(51,63)$. Modifications of the $\mathrm{SCH}$ system that attempt to more closely mimic the in vivo architecture (e.g., co-cultures, scaffolds and other extracellular matrices, microfluidic devices) continue to be explored. Whether these more sophisticated models will provide significant advantages to transporter scientists selecting the optimal model from their drug development toolkit remains to be determined.

\section{Integration of In Vitro Transporter Data}

Selection of appropriate in vitro tool(s) to investigate the role of transporters in compound disposition depends on the scientific hypotheses that need to be addressed. Table 4 summarizes strengths and weaknesses of the various in vitro transporter assay systems. Table 5 outlines several potential in vitro strategies to address specific questions that may arise during drug discovery and development related to the role of transporters in absorption, distribution, clearance, and drug interactions; alternate model systems and/or approaches are included. Typically, these questions originate from preclinical in vivo findings, clinical observations and/or prior knowledge about the disposition of compounds with similar chemical structures. For example, if the systemic exposure of a compound following oral administration does not increase proportionately with increasing dose in preclinical studies, questions about possible involvement of transporters in drug absorption may arise. Appropriate in vitro strategies, guided by physicochemical properties (64) or data generated from in silico modeling, can be applied to assess the role of transporters in active uptake and/or apical efflux. Although the results may support involvement of a transporter mechanism relevant to a particular preclinical species, 
extrapolation between species often is not possible due to species differences in substrate specificity, transporter expression, and/or absolute protein levels.

An in vitro experimental strategy may involve multiple steps using different model systems, requiring stepwise or parallel integration of the information generated. This approach extends beyond the questions of whether or not a compound is a substrate or inhibitor of a specific transporter. Such questions can be addressed using well-validated model systems, as described earlier and outlined in Table 4. The ultimate goal of an experimental strategy is to integrate all available experimental transporter data to better understand drug disposition and predict the propensity for transporter-mediated drug interactions in humans.

With the availability of many transporter assays and assay formats, a vast amount of data can be generated for compounds during the development process. Often, different experimental approaches can be applied to address the same scientific question as long as the experiments are designed appropriately, the assumptions about each experimental system and the behavior of the compound in each system are correct, and the limitations have been considered. A formidable challenge with the availability of multiple in vitro assays is determining the in vivo relevance of information generated, and specifically how transporter data can be translated to the clinical situation. Generation of transporter data should not be viewed simply as a "box-checking" exercise during the drug development process. Instead, factors such as therapeutic indication, possible co-medications in the target patient population, and therapeutic index should be taken into account. Developing a drug transporter assessment strategy, including the timing and selection of transporters to be investigated, is an important part of the development plan, as discussed in detail by Tweedie et al. (see this issue).

The role of transporters in the disposition of a compound can be assessed from either a "bottom up" or "top down" approach. In the former, information on transporters is obtained prior to clinical studies and these results are scaled or modeled to gain insight into the clinical relevance of this information. The "top down" approach relies first on the generation of clinical 
data, and subsequent assessment of transporter involvement to explain clinical findings and define a plan for further clinical development. The risk with the "bottom up" approach is the possibility that data generated are not relevant or are difficult to interpret. In contrast, the "top down" approach may reveal critical transporter issues in advanced stages of drug development that no longer can be mitigated, rather only managed through the final development process. The optimal approach customizes the transporter assessment strategy based on project-specific needs, uses translatable in vivo and in vitro models, and integrates knowledge (e.g., preclinical data, physicochemical properties, in silico modeling, and/or frequently co-administered drugs) to drive the need for information about the involvement of transporter(s), and the relative contribution of individual transporters in disposition of the compound. If transport proteins are involved in absorption, clearance and/or distribution of the compound, then follow-up studies to assess a DDI liability would be necessary as discussed in the FDA and EMA guidance documents

(http://www.fda.gov/downloads/Drugs/GuidanceComplianceRegulatorylnformation/Guidances/U CM292362.pdf; www.ema.europa.eu). If no interactions with the compound and multiple transporter probe substrates or inhibitors are observed, then the potential for transporter-based DDIs will be low, and further studies may not be necessary or could be delayed to a later stage of development. If an interaction is observed, further studies will be necessary to identify the transporter(s) involved in the uptake or efflux of the compound and its metabolites under evaluation using information from multiple transporter probe substrates and inhibitors in whole cell systems, membrane vesicles and/or transport assays utilizing recombinant systems. This approach may provide a practical "real world" evaluation of the compound by first determining if a potential problem exists, and secondly providing direction to evaluate the involvement of specific uptake and/or efflux transporters.

Knowledge regarding unbound drug concentrations at the relevant sites may aid in determining the clinical relevance of in vitro data. As drug transporter science evolves, an 
understanding of disease state alterations in transporters (e.g., altered hepatic transporters in cholestasis (65), and non-alcoholic steatohepatitis (66)), and elucidation of complex mechanisms of drug-transporter interactions other than competitive inhibition (e.g., timedependent inhibition of hepatic uptake by cyclosporine A (67)) may help translate in vitro data to the clinical situation. In vitro DDI studies should be designed to elucidate the potential role of the compound as a "victim" and/or "perpetrator", preferably with clinically relevant transporter probe substrates or inhibitors, and incorporation of relevant positive controls (Tables 1 and 2). More dedicated clinical studies are needed to evaluate the sensitivity of "clinically relevant probes" currently listed in Table 2 for a given transporter.

Careful consideration is needed when integrating transporter data from several experimental systems. Many compounds are transported by more than one uptake or efflux protein and also may be metabolized in vivo. Since analyses in membrane vesicles or transfected cell lines usually only takes into account a single transporter of interest, differences in results compared to data generated in intact primary cells may be attributed to compound transport by alternate mechanisms present in these more complex systems. Such transporter multiplicity becomes especially important when assessing the clinical relevance of drug interactions of victim drugs that may have competing clearance mechanisms. Cell lines also lack relevant drug metabolizing enzymes that may impact the overall disposition of a compound. Primary cells such as hepatocytes represent a more holistic in-vivo system capable of expressing many of the relevant drug transporters and drug metabolizing enzymes in culture, and theoretically should be helpful in establishing the rate-determining step in drug elimination. When considering the integration of in vitro results with in vivo observations, one must also consider transporter differences across species (68), the impact of protein binding on unbound drug available to interact with transporters, and blood flow that may be rate-limiting in delivery of a compound to the site of transport. 
Despite each individual system's limitations, data from these models can be integrated effectively to gain insight concerning transporter-related ADME questions. For example, hepatocytes in suspension in conjunction with transfected cell lines are valuable to assess the relative role of OATPs in the uptake of drug substrates. These combined data can be more quantitative in the estimation of DDI risk than studies with transfected cell lines alone (69). SCH are a useful approach to assess overall biliary excretion of a compound to identify transporter involvement. Coupling these data with information generated in vesicles from cell lines overexpressing the transporter of interest can help define the actual mechanism(s) of canalicular excretion. Although the role of transporters in toxicity is still emerging, transport mechanisms have been implicated as possible causes for elevated serum bile acids (cholestasis), and elevated conjugated bilirubin (conjugated hyperbilirubinemia). For example, BSEP inhibition has been attributed to an increase in the risk for cholestatic drug-induced liver injury $(70,71)$. However, many compounds that inhibit BSEP do not cause cholestasis. Integration of inhibition data from BSEP-expressing membrane vesicles with $\mathrm{SCH}$ data, where intracellular concentrations of parent compound and potential metabolites can be assessed, and the impact on BSEP and other hepatic bile acid uptake and efflux transporters can be examined, may better predict the ultimate clinical impact of drug-induced transporter-mediated alterations in bile acid disposition (55). In the case where hyperbilirubinemia (in particular the conjugated species) is observed clinically with a lead compound, OATP-overexpressing cell lines, hepatocyte uptake and inhibition studies, MRP2 vesicle inhibition assays, and assessment of UGT1A1 inhibition may be useful in assessing potential clinical liabilities of closely related backup compounds being considered for development. A complementary, integrative approach is to use human $\mathrm{SCH}$ to characterize the effects of a compound (and generated metabolites) on the hepatobiliary disposition of bilirubin and its glucuronide conjugates (72).

Recently, efforts have been initiated to incorporate data from different in vitro models into translational pharmacokinetic models, including PBPK models (Zamek-Gliszczynski et al., 
see this issue) to maximize interpretation of the data, explain in vivo findings, and predict transporter-mediated alterations in pharmacokinetics/pharmacodynamics and drug interactions $(58,73)$. The complexity of biological systems coupled with the multitude of factors that influence the ultimate endpoints of drug efficacy and toxicity in patients, highlights the necessity of comprehensive modeling and simulation approaches to understand and predict transportermediated changes in drug disposition in humans.

The development and use of in vitro transporter assays has greatly advanced our understanding of the role that transport mechanisms can play in drug disposition and drug interactions. The abundance of available in vitro tools has enabled the testing of transporterrelated hypotheses in complementary assays, often allowing for enhanced understanding of how transporters interact with novel chemical entities. Although the emergence of tools has facilitated easier assessment of transporter function, the availability of many different transporter assays has emphasized the need for additional research. The use of validated, standardized probe substrates and inhibitors with the requisite specificity for transporter mechanisms is critical in interpreting transporter assay data. Examples of in vitro correlations of transporter data with in vivo clinical data have emerged, but continued efforts are needed to establish validation criteria for transporter assays and to better define the utility of probe substrates and inhibitors in clinical DDI studies.

\section{Outlook}

The field of drug transport continues to evolve at an accelerated pace. Integration of in vitro transporter data into modeling approaches such as physiologically-based PK/PD modeling should further improve the quantitative prediction of the effect of transporters on drug absorption, disposition, and DDIs. A sound strategy for the evaluation of drug transporters will rely on the integration of multiple transporter assays to translate specific mechanisms of transport to overall in vivo disposition. As novel transporter assays continue to be developed 
and existing assays are refined to better mimic the in vivo setting, the paradigms for in vitro and in vivo transporter evaluation will evolve in parallel to better predict the clinical impact of these mechanisms on safe, effective therapies for patients.

\section{Figure legends}

Figure 1. Scheme for transport assays for ATP-dependent efflux pumps. After isolation of plasma membranes from $A B C$ transporter-expressing cells, a mixture of inside-out and rightside-out membrane vesicles can be formed. Only the inside-out-oriented vesicle fraction reacts with ATP to transport substrates into the vesicle, while 5'-AMP serves as a negative control. Vesicles containing the substrates can be isolated on filter membranes in the case of most transport substrates, however, for very hydrophobic substrates, which bind strongly to the filter membranes, centrifugation through a small gel matrix column may be preferable $(12,13,74)$. Detection of intra-vesicular substrates may be based on radioactivity, fluorescence, LC/MS, or LC/MS/MS.

Figure 2. ATP-dependent transport of ${ }^{3} \mathrm{H}$-labeled leukotriene $\mathrm{C}_{4}(50 \mathrm{nM})$ into plasma membrane vesicles containing ABCC1 (MRP1). Transport in the presence of 4 mM ATP or 4 mM 5'-AMP is shown in the left panel; net ATP-dependent transport on the right. The quinoline-based LTD4 receptor antagonist MK-0571 $(5 \mu \mathrm{M})$ is a potent inhibitor of MRP1-mediated transport (12). Reproduced with permission from Methods in Enzymology 292:613, 1998.

Figure 3. Schematic representation of transport through polarized cell monolayers (Panel A), and transport studies in sandwich-cultured hepatocytes (Panel B). 


\section{Acknowledgements:}

This work was supported, in part, by funding from the National Institutes of Health through award number R01GM41935 (KLRB) from the National Institute of General Medical Sciences. The content is solely the responsibility of the authors and does not necessarily represent the official views of the National Institutes of Health.

\section{Disclosure:}

KLRB is chair of the Scientific Advisory Board for Qualyst Transporter Solutions, which has exclusively licensed sandwich-cultured hepatocytes for quantification of hepatobiliary drug disposition (including B-CLEAR ${ }^{\circledR}$ and related technologies). 


\section{References}

1. Giacomini KM, Huang SM, Tweedie DJ, Benet LZ, Brouwer KL, Chu X, et al. Membrane transporters in drug development. Nature reviews Drug discovery. 2010;9(3):215-36. Epub 2010/03/02.

2. Morrissey KM, Wen CC, Johns SJ, Zhang L, Huang SM, Giacomini KM. The UCSF-FDA TransPortal: a public drug transporter database. Clinical pharmacology and therapeutics. 2012;92(5):545-6. Epub 2012/10/23.

3. Zamek-Gliszczynski MJ, Hoffmaster KA, Tweedie DJ, Giacomini KM, Hillgren KM. Highlights from the International Transporter Consortium second workshop. Clinical pharmacology and therapeutics. 2012;92(5):553-6. Epub 2012/10/23.

4. Feng B, Mills JB, Davidson RE, Mireles RJ, Janiszewski JS, Troutman MD, et al. In vitro Pglycoprotein assays to predict the in vivo interactions of P-glycoprotein with drugs in the central nervous system. Drug metabolism and disposition: the biological fate of chemicals. 2008;36(2):268-75. Epub 2007/10/27.

5. Yamazaki M, Neway WE, Ohe T, Chen I, Rowe JF, Hochman JH, et al. In vitro substrate identification studies for p-glycoprotein-mediated transport: species difference and predictability of in vivo results. The Journal of pharmacology and experimental therapeutics. 2001;296(3):723-35. Epub 2001/02/22.

6. Hirano M, Maeda K, Shitara Y, Sugiyama Y. Contribution of OATP2 (OATP1B1) and OATP8 (OATP1B3) to the hepatic uptake of pitavastatin in humans. The Journal of pharmacology and experimental therapeutics. 2004;311(1):139-46. Epub 2004/05/26.

7. Bjornsson TD, Callaghan JT, Einolf HJ, Fischer V, Gan L, Grimm S, et al. The conduct of in vitro and in vivo drug-drug interaction studies: a Pharmaceutical Research and Manufacturers of America (PhRMA) perspective. Drug metabolism and disposition: the biological fate of chemicals. 2003;31(7):81532. Epub 2003/06/20.

8. Kondo T, Dale GL, Beutler E. Glutathione transport by inside-out vesicles from human erythrocytes. Proceedings of the National Academy of Sciences of the United States of America. 1980;77(11):6359-62. Epub 1980/11/01.

9. Ahlin G, Hilgendorf C, Karlsson J, Szigyarto CA, Uhlen M, Artursson P. Endogenous gene and protein expression of drug-transporting proteins in cell lines routinely used in drug discovery programs. Drug metabolism and disposition: the biological fate of chemicals. 2009;37(12):2275-83. Epub 2009/09/11.

10. Meier PJ, Boyer JL. Preparation of basolateral (sinusoidal) and canalicular plasma membrane vesicles for the study of hepatic transport processes. Methods in enzymology. 1990;192:534-45. Epub 1990/01/01.

11. Tabas LB, Dantzig AH. A high-throughput assay for measurement of multidrug resistance protein-mediated transport of leukotriene $\mathrm{C} 4$ into membrane vesicles. Analytical biochemistry. 2002;310(1):61-6. Epub 2002/11/05.

12. Keppler D, Jedlitschky G, Leier I. Transport function and substrate specificity of multidrug resistance protein. Methods in enzymology. 1998;292:607-16. Epub 1998/08/26.

13. Bohme M, Muller M, Leier I, Jedlitschky G, Keppler D. Cholestasis caused by inhibition of the adenosine triphosphate-dependent bile salt transport in rat liver. Gastroenterology. 1994;107(1):25565. Epub 1994/07/01.

14. Loe DW, Deeley RG, Cole SP. Characterization of vincristine transport by the $M(r) 190,000$ multidrug resistance protein (MRP): evidence for cotransport with reduced glutathione. Cancer research. 1998;58(22):5130-6. Epub 1998/11/21. 
15. Bakos E, Evers R, Sinko E, Varadi A, Borst P, Sarkadi B. Interactions of the human multidrug resistance proteins MRP1 and MRP2 with organic anions. Molecular pharmacology. 2000;57(4):760-8. Epub 2000/03/23.

16. Rius M, Nies AT, Hummel-Eisenbeiss J, Jedlitschky G, Keppler D. Cotransport of reduced glutathione with bile salts by MRP4 (ABCC4) localized to the basolateral hepatocyte membrane. Hepatology. 2003;38(2):374-84. Epub 2003/07/29.

17. Evers R, de Haas M, Sparidans R, Beijnen J, Wielinga PR, Lankelma J, et al. Vinblastine and sulfinpyrazone export by the multidrug resistance protein MRP2 is associated with glutathione export. British journal of cancer. 2000;83(3):375-83. Epub 2000/08/06.

18. Zelcer N, Huisman MT, Reid G, Wielinga P, Breedveld P, Kuil A, et al. Evidence for two interacting ligand binding sites in human multidrug resistance protein 2 (ATP binding cassette $C 2$ ). The Journal of biological chemistry. 2003;278(26):23538-44. Epub 2003/04/19.

19. de Waart DR, Hausler S, Vlaming ML, Kunne C, Hanggi E, Gruss HJ, et al. Hepatic transport mechanisms of cholyl-L-lysyl-fluorescein. The Journal of pharmacology and experimental therapeutics. 2010;334(1):78-86. Epub 2010/04/15.

20. de Graaf W, Hausler S, Heger M, van Ginhoven TM, van Cappellen G, Bennink RJ, et al. Transporters involved in the hepatic uptake of $(99 \mathrm{~m})$ Tc-mebrofenin and indocyanine green. Journal of hepatology. 2011;54(4):738-45. Epub 2010/12/18.

21. Jacquemin E, Hagenbuch B, Stieger B, Wolkoff AW, Meier PJ. Expression cloning of a rat liver $\mathrm{Na}(+)$-independent organic anion transporter. Proceedings of the National Academy of Sciences of the United States of America. 1994;91(1):133-7. Epub 1994/01/04.

22. Kessler M, Tannenbaum V, Tannenbaum C. A simple apparatus for performing short-time (1--2 seconds) uptake measurements in small volumes; its application to D-glucose transport studies in brush border vesicles from rabbit jejunum and ileum. Biochimica et biophysica acta. 1978;509(2):348-59. Epub 1978/05/18.

23. Schomig E, Lazar A, Grundemann D. Extraneuronal monoamine transporter and organic cation transporters 1 and 2: a review of transport efficiency. Handb Exp Pharmacol. 2006(175):151-80. Epub 2006/05/26.

24. O'Gorman S, Fox DT, Wahl GM. Recombinase-mediated gene activation and site-specific integration in mammalian cells. Science. 1991;251(4999):1351-5. Epub 1991/03/15.

25. Keppler D. Uptake and efflux transporters for conjugates in human hepatocytes. Methods in enzymology. 2005;400:531-42. Epub 2006/01/10.

26. Shitara Y, Horie T, Sugiyama Y. Transporters as a determinant of drug clearance and tissue distribution. European journal of pharmaceutical sciences : official journal of the European Federation for Pharmaceutical Sciences. 2006;27(5):425-46. Epub 2006/02/21.

27. Yonezawa A, Inui K. Importance of the multidrug and toxin extrusion MATE/SLC47A family to pharmacokinetics, pharmacodynamics/toxicodynamics and pharmacogenomics. British journal of pharmacology. 2011;164(7):1817-25. Epub 2011/04/05.

28. Tran TT, Mittal A, Aldinger T, Polli JW, Ayrton A, Ellens H, et al. The elementary mass action rate constants of P-gp transport for a confluent monolayer of MDCKII-hMDR1 cells. Biophysical journal. 2005;88(1):715-38. Epub 2004/10/27.

29. Acharya P, O'Connor MP, Polli JW, Ayrton A, Ellens H, Bentz J. Kinetic identification of membrane transporters that assist P-glycoprotein-mediated transport of digoxin and loperamide through a confluent monolayer of MDCKII-hMDR1 cells. Drug metabolism and disposition: the biological fate of chemicals. 2008;36(2):452-60. Epub 2007/10/31.

30. Bartholome K, Rius M, Letschert K, Keller D, Timmer J, Keppler D. Data-based mathematical modeling of vectorial transport across double-transfected polarized cells. Drug metabolism and disposition: the biological fate of chemicals. 2007;35(9):1476-81. Epub 2007/06/06. 
31. Sharom FJ, Lugo MR, Eckford PD. New insights into the drug binding, transport and lipid flippase activities of the p-glycoprotein multidrug transporter. J Bioenerg Biomembr. 2005;37(6):481-7. Epub 2006/05/13.

32. Kalvass JC, Pollack GM. Kinetic considerations for the quantitative assessment of efflux activity and inhibition: implications for understanding and predicting the effects of efflux inhibition. Pharmaceutical research. 2007;24(2):265-76. Epub 2006/12/28.

33. Lumen AA, Acharya P, Polli JW, Ayrton A, Ellens H, Bentz J. If the $\mathrm{KI}$ is defined by the free energy of binding to P-glycoprotein, which kinetic parameters define the IC50 for the Madin-Darby canine kidney II cell line overexpressing human multidrug resistance 1 confluent cell monolayer? Drug metabolism and disposition: the biological fate of chemicals. 2010;38(2):260-9. Epub 2009/11/06.

34. Hayeshi R, Hilgendorf C, Artursson P, Augustijns P, Brodin B, Dehertogh $P$, et al. Comparison of drug transporter gene expression and functionality in Caco-2 cells from 10 different laboratories. European journal of pharmaceutical sciences : official journal of the European Federation for Pharmaceutical Sciences. 2008;35(5):383-96. Epub 2008/09/11.

35. Hubatsch I, Ragnarsson EG, Artursson P. Determination of drug permeability and prediction of drug absorption in Caco-2 monolayers. Nature protocols. 2007;2(9):2111-9. Epub 2007/09/15.

36. Hidalgo IJ, Raub TJ, Borchardt RT. Characterization of the human colon carcinoma cell line (Caco2) as a model system for intestinal epithelial permeability. Gastroenterology. 1989;96(3):736-49. Epub 1989/03/01.

37. Volpe DA. Drug-permeability and transporter assays in Caco-2 and MDCK cell lines. Future medicinal chemistry. 2011;3(16):2063-77. Epub 2011/11/22.

38. Thiel-Demby VE, Humphreys JE, St John Williams LA, Ellens HM, Shah N, Ayrton AD, et al. Biopharmaceutics classification system: validation and learnings of an in vitro permeability assay. Molecular pharmaceutics. 2009;6(1):11-8. Epub 2009/02/28.

39. LeCluyse EL, Bullock PL, Parkinson A, Hochman JH. Cultured rat hepatocytes. Pharm Biotechnol. 1996;8:121-59. Epub 1996/01/01.

40. Hoffmaster KA, Zamek-Gliszczynski MJ, Pollack GM, Brouwer KL. Multiple transport systems mediate the hepatic uptake and biliary excretion of the metabolically stable opioid peptide [Dpenicillamine2,5]enkephalin. Drug metabolism and disposition: the biological fate of chemicals. 2005;33(2):287-93. Epub 2004/11/06.

41. Yabe Y, Galetin A, Houston JB. Kinetic characterization of rat hepatic uptake of 16 actively transported drugs. Drug metabolism and disposition: the biological fate of chemicals. 2011;39(10):180814.

42. Leslie EM, Watkins PB, Kim RB, Brouwer KL. Differential inhibition of rat and human Na+dependent taurocholate cotransporting polypeptide (NTCP/SLC10A1)by bosentan: a mechanism for species differences in hepatotoxicity. The Journal of pharmacology and experimental therapeutics. 2007;321(3):1170-8. Epub 2007/03/22.

43. Haussinger D, Lang F, Gerok W. Regulation of cell function by the cellular hydration state. The American journal of physiology. 1994;267(3 Pt 1):E343-55. Epub 1994/09/01.

44. Li M, Yuan H, Li N, Song G, Zheng Y, Baratta M, et al. Identification of interspecies difference in efflux transporters of hepatocytes from dog, rat, monkey and human. European journal of pharmaceutical sciences : official journal of the European Federation for Pharmaceutical Sciences. 2008;35(1-2):114-26. Epub 2008/07/22.

45. Ishigami M, Tokui T, Komai T, Tsukahara K, Yamazaki M, Sugiyama Y. Evaluation of the uptake of pravastatin by perfused rat liver and primary cultured rat hepatocytes. Pharmaceutical research. 1995;12(11):1741-5. Epub 1995/11/01. 
46. Houle R, Raoul J, Levesque JF, Pang KS, Nicoll-Griffith DA, Silva JM. Retention of transporter activities in cryopreserved, isolated rat hepatocytes. Drug metabolism and disposition: the biological fate of chemicals. 2003;31(4):447-51. Epub 2003/03/19.

47. Jorgensen L, Van Beek J, Lund S, Schousboe A, Badolo L. Evidence of Oatp and Mdr1 in cryopreserved rat hepatocytes. European journal of pharmaceutical sciences: official journal of the European Federation for Pharmaceutical Sciences. 2007;30(2):181-9. Epub 2006/12/19.

48. Bow DA, Perry JL, Miller DS, Pritchard JB, Brouwer KL. Localization of P-gp (Abcb1) and Mrp2 (Abcc2) in freshly isolated rat hepatocytes. Drug metabolism and disposition: the biological fate of chemicals. 2008;36(1):198-202. Epub 2007/10/24.

49. Kimoto E, Yoshida K, Balogh LM, Bi YA, Maeda K, El-Kattan A, et al. Characterization of Organic Anion Transporting Polypeptide (OATP) Expression and Its Functional Contribution to the Uptake of Substrates in Human Hepatocytes. Molecular pharmaceutics. 2012. Epub 2012/10/23.

50. Soars MG, Grime K, Sproston JL, Webborn PJ, Riley RJ. Use of hepatocytes to assess the contribution of hepatic uptake to clearance in vivo. Drug metabolism and disposition: the biological fate of chemicals. 2007;35(6):859-65. Epub 2007/03/09.

51. Swift B, Pfeifer ND, Brouwer KL. Sandwich-cultured hepatocytes: an in vitro model to evaluate hepatobiliary transporter-based drug interactions and hepatotoxicity. Drug metabolism reviews. 2010;42(3):446-71. Epub 2010/01/30.

52. Bi YA, Kimoto E, Sevidal S, Jones HM, Barton HA, Kempshall S, et al. In vitro evaluation of hepatic transporter-mediated clinical drug-drug interactions: hepatocyte model optimization and retrospective investigation. Drug metabolism and disposition: the biological fate of chemicals. 2012;40(6):1085-92. Epub 2012/03/03.

53. Liu X, LeCluyse EL, Brouwer KR, Lightfoot RM, Lee JI, Brouwer KL. Use of Ca2+ modulation to evaluate biliary excretion in sandwich-cultured rat hepatocytes. The Journal of pharmacology and experimental therapeutics. 1999;289(3):1592-9.

54. Hoffmaster KA, Turncliff RZ, LeCluyse EL, Kim RB, Meier PJ, Brouwer KL. P-glycoprotein expression, localization, and function in sandwich-cultured primary rat and human hepatocytes: relevance to the hepatobiliary disposition of a model opioid peptide. Pharmaceutical research. 2004;21(7):1294-302. Epub 2004/08/05.

55. Lee JK, Marion TL, Abe K, Lim C, Pollock GM, Brouwer KL. Hepatobiliary disposition of troglitazone and metabolites in rat and human sandwich-cultured hepatocytes: use of Monte Carlo simulations to assess the impact of changes in biliary excretion on troglitazone sulfate accumulation. The Journal of pharmacology and experimental therapeutics. 2010;332(1):26-34. Epub 2009/10/06.

56. Li N, Singh P, Mandrell KM, Lai Y. Improved extrapolation of hepatobiliary clearance from in vitro sandwich cultured rat hepatocytes through absolute quantification of hepatobiliary transporters. Molecular pharmaceutics. 2010;7(3):630-41. Epub 2010/05/05.

57. Jones HM, Barton HA, Lai Y, Bi YA, Kimoto E, Kempshall S, et al. Mechanistic pharmacokinetic modeling for the prediction of transporter-mediated disposition in humans from sandwich culture human hepatocyte data. Drug metabolism and disposition: the biological fate of chemicals.

2012;40(5):1007-17. Epub 2012/02/22.

58. Yan GZ, Generaux CN, Yoon M, Goldsmith RB, Tidwell RR, Hall JE, et al. A semiphysiologically based pharmacokinetic modeling approach to predict the dose-exposure relationship of an antiparasitic prodrug/active metabolite pair. Drug metabolism and disposition: the biological fate of chemicals. 2012;40(1):6-17. Epub 2011/09/29.

59. Abe K, Bridges AS, Yue W, Brouwer KL. In vitro biliary clearance of angiotensin II receptor blockers and 3-hydroxy-3-methylglutaryl-coenzyme $A$ reductase inhibitors in sandwich-cultured rat hepatocytes: comparison with in vivo biliary clearance. The Journal of pharmacology and experimental therapeutics. 2008;326(3):983-90. Epub 2008/06/25. 
60. Fukuda $\mathrm{H}$, Ohashi R, Tsuda-Tsukimoto $\mathrm{M}$, Tamai I. Effect of plasma protein binding on in vitro-in vivo correlation of biliary excretion of drugs evaluated by sandwich-cultured rat hepatocytes. Drug metabolism and disposition: the biological fate of chemicals. 2008;36(7):1275-82. Epub 2008/04/05.

61. Abe K, Bridges AS, Brouwer KL. Use of sandwich-cultured human hepatocytes to predict biliary clearance of angiotensin II receptor blockers and HMG-CoA reductase inhibitors. Drug metabolism and disposition: the biological fate of chemicals. 2009;37(3):447-52. Epub 2008/12/17.

62. Ghibellini G, Vasist LS, Leslie EM, Heizer WD, Kowalsky RJ, Calvo BF, et al. In vitro-in vivo correlation of hepatobiliary drug clearance in humans. Clinical pharmacology and therapeutics. 2007;81(3):406-13. Epub 2007/01/20.

63. Chandra $\mathrm{P}$, Zhang $\mathrm{P}$, Brouwer KL. Short-term regulation of multidrug resistance-associated protein 3 in rat and human hepatocytes. American journal of physiology Gastrointestinal and liver physiology. 2005;288(6):G1252-8. Epub 2005/01/15.

64. Benet LZ. The role of BCS (biopharmaceutics classification system) and BDDCS (biopharmaceutics drug disposition classification system) in drug development. Journal of pharmaceutical sciences. 2013;102(1):34-42. Epub 2012/11/14.

65. Pauli-Magnus C, Meier PJ. Hepatobiliary transporters and drug-induced cholestasis. Hepatology. 2006;44(4):778-87. Epub 2006/09/29.

66. Hardwick RN, Fisher CD, Canet MJ, Scheffer GL, Cherrington NJ. Variations in ATP-binding cassette transporter regulation during the progression of human nonalcoholic fatty liver disease. Drug metabolism and disposition: the biological fate of chemicals. 2011;39(12):2395-402. Epub 2011/09/01.

67. Shitara Y, Takeuchi K, Nagamatsu Y, Wada S, Sugiyama Y, Horie T. Long-lasting inhibitory effects of cyclosporin A, but not tacrolimus, on OATP1B1- and OATP1B3-mediated uptake. Drug metabolism and pharmacokinetics. 2012;27(4):368-78. Epub 2012/01/14.

68. Chu X, Bleasby K, Evers R. Species differences in drug transporters and implications for translating preclinical findings to humans. Expert Opin Drug Metab Toxicol. 2013;9(3):237-52. Epub 2012/12/22.

69. Yoshida K, Maeda K, Sugiyama Y. Hepatic and intestinal drug transporters: prediction of pharmacokinetic effects caused by drug-drug interactions and genetic polymorphisms. Annual review of pharmacology and toxicology. 2013;53:581-612. Epub 2012/11/13.

70. Dawson S, Stahl S, Paul N, Barber J, Kenna JG. In vitro inhibition of the bile salt export pump correlates with risk of cholestatic drug-induced liver injury in humans. Drug metabolism and disposition: the biological fate of chemicals. 2012;40(1):130-8. Epub 2011/10/04.

71. Morgan RE, Trauner M, van Staden CJ, Lee PH, Ramachandran B, Eschenberg M, et al. Interference with bile salt export pump function is a susceptibility factor for human liver injury in drug development. Toxicological sciences : an official journal of the Society of Toxicology. 2010;118(2):485500. Epub 2010/09/11.

72. Lee K, Hart R, Brouwer K. P187. Hepatobiliary disposition of bilirubin and its mono- and diglucuronide metabolites in sandwich-cultured rat hepatocytes. Drug metabolism reviews. 2011;43(S2):128-9.

73. Turncliff RZ, Hoffmaster KA, Kalvass JC, Pollack GM, Brouwer KL. Hepatobiliary disposition of a drug/metabolite pair: Comprehensive pharmacokinetic modeling in sandwich-cultured rat hepatocytes. The Journal of pharmacology and experimental therapeutics. 2006;318(2):881-9. Epub 2006/05/13.

74. Jedlitschky G, Leier I, Buchholz U, Barnouin K, Kurz G, Keppler D. Transport of glutathione, glucuronate, and sulfate conjugates by the MRP gene-encoded conjugate export pump. Cancer research. 1996;56(5):988-94. Epub 1996/03/01. 


\section{Table 1. Recommended Probe Substrates and Inhibitors for Human ATP-dependent Transport into Membrane Vesicles}

\begin{tabular}{|c|c|c|}
\hline Transporter & Assay Substrates & Inhibitors \\
\hline ABCB1 (MDR1 P-gp) & {$\left[{ }^{3} \mathrm{H}\right]-\mathrm{N}$-methyl-quinidine (1) } & $\begin{array}{l}\text { GF120918 (2) } \\
\text { Cyclosporin A } \\
\text { PSC833 }\end{array}$ \\
\hline ABCG2 (BCRP) & $\begin{array}{l}\text { Mitoxantrone (2), } \\
{\left[{ }^{3} \mathrm{H}\right]-\text {-Methotrexate (3) }} \\
\text { Estrone 3-Sulfate }\end{array}$ & $\begin{array}{l}\text { Ko143(2) } \\
\text { GF120918 (4) }\end{array}$ \\
\hline ABCC1 (MRP1) & $\begin{array}{l}{\left[{ }^{3} \mathrm{H}\right] \text {-Leukotriene } \mathrm{C}_{4}(5,6),} \\
{\left[{ }^{3} \mathrm{H}\right] \text {-Estradiol } 17 \text {-glucuronide }(5)} \\
{\left[{ }^{14} \mathrm{C}\right] \text {-Ethacrynyl glutathione }(7)}\end{array}$ & MK-571 (5) \\
\hline ABCC2 (MRP2) & $\begin{array}{l}{\left[{ }^{3} \mathrm{H}\right] \text {-Leukotriene } \mathrm{C}_{4}(5),} \\
{\left[{ }^{3} \mathrm{H}\right] \text {-Estradiol } 17 \text {-glucuronide }(2)} \\
{\left[{ }^{14} \mathrm{C}\right] \text {-Ethacrynyl glutathione }(8)} \\
\text { Carboxy-dichlorofluorescein }(9,10)\end{array}$ & MK-571 (5) \\
\hline ABCC3 (MRP3) & $\begin{array}{l}{\left[{ }^{3} \mathrm{H}\right] \text {-Estradiol 17ß-glucuronide (11) }} \\
\text { Carboxy-dichlorofluorescein (9) }\end{array}$ & $\begin{array}{l}\text { Bromosulfophthalein } \\
\text { MK-571 }\end{array}$ \\
\hline ABCC4 (MRP4) & $\begin{array}{l}{\left[{ }^{3} \mathrm{H}\right] \text {-Leukotriene C4 (12) }} \\
{\left[{ }^{3} \mathrm{H}\right] \text {-Dehydroepiandrosterone 3-sulfate (DHEAS) (13) }} \\
{\left[{ }^{3} \mathrm{H}\right] \text {-Folate }(14)}\end{array}$ & MK-571 (5) \\
\hline ABCB11 (BSEP) & {$\left[{ }^{3} \mathrm{H}\right]-$ Taurocholate (cholyltaurine) $(10)$} & $\begin{array}{l}\text { Cyclosporin A (10) } \\
\text { PSC-833 }\end{array}$ \\
\hline
\end{tabular}

References listed in this table are located in supplementary material available online. 
Table 2. Recommended Transporter Probe Substrates and Inhibitors Commonly Used in Single Transfected Cell Systems or Caco-2 Cells, and Potential Clinical Probes

\begin{tabular}{|c|c|c|c|c|}
\hline Transporter & $\begin{array}{l}\text { Recommended In } \\
\text { Vitro System(s) }\end{array}$ & Positive Control Substrates & Inhibitors & $\begin{array}{l}\text { Potential } \\
\text { Therapeutic } \\
\text { Drug } \\
\text { Substrates }\end{array}$ \\
\hline ABCB1 (MDR1 P-gp) & $\begin{array}{l}\text { LLC-MDR1 } \\
\text { MDCK-MDR1 } \\
\text { Caco-2 }\end{array}$ & $\begin{array}{l}\text { Digoxin (15) } \\
\text { Verapamil (16) } \\
\text { Talinolol (17) } \\
\text { Amprenavir (18) }\end{array}$ & $\begin{array}{l}\text { GF120918 (19) } \\
\text { Ketoconazole (19) } \\
\text { Verapamil (19) } \\
\text { Cyclosporin A (19) } \\
\text { PSC833 (20) }\end{array}$ & Digoxin \\
\hline ABCG2 (BCRP) & $\begin{array}{l}\text { MDCK-BCRP } \\
\text { Caco-2 }\end{array}$ & $\begin{array}{l}\text { Prazosin (21) } \\
\text { Sulfasalazine (Caco-2) (22) } \\
\text { Cimetidine (23) }\end{array}$ & $\begin{array}{l}\text { Ko143 (24) } \\
\text { GF120918 (4) }\end{array}$ & $\begin{array}{l}\text { Rosuvastatin } \\
\text { Methotrexate }\end{array}$ \\
\hline $\mathrm{ABCC2}(\mathrm{MRP} 2)^{\mathrm{a}}$ & MDCK-MRP2 & $\begin{array}{l}\text { Vinblastine (8) } \\
\text { Paclitaxel/Docetaxel (25) }\end{array}$ & $\begin{array}{l}\text { MK-571 (26) } \\
\text { Probenecid (27) } \\
\text { Cyclosporin A (28) } \\
\text { PSC833(29, 30) }\end{array}$ & $\begin{array}{l}\text { Vinblastine } \\
\text { Cyclosporin A }\end{array}$ \\
\hline $\mathrm{OCT1}^{\mathrm{a}}(S L C 22 A 1)$ & $\begin{array}{l}\text { CHO-OCT1 } \\
\text { HEK293-OCT1 }\end{array}$ & $\begin{array}{l}\text { Tetraethyl ammonium (31) } \\
\text { 1-methyl-4-phenylpyridinium (31) } \\
\text { Metformin (31) }\end{array}$ & $\begin{array}{l}\text { Decynium-22 (31) } \\
\text { Quinidine (31) } \\
\text { Verapamil (31) }\end{array}$ & $\begin{array}{l}\text { Metformin } \\
\text { Lamivudine }\end{array}$ \\
\hline $\mathrm{OCT2}^{\mathrm{a}}(S L C 22 A 2)$ & $\begin{array}{l}\text { CHO-OCT2 } \\
\text { HEK293-OCT2 }\end{array}$ & $\begin{array}{l}\text { Tetraethyl ammonium (31) } \\
\text { Metformin (31) }\end{array}$ & Decynium-22 (31) & $\begin{array}{l}\text { Metformin } \\
\text { Lamivudine }\end{array}$ \\
\hline OAT1 (SLC22A6) & $\begin{array}{l}\text { CHO-OAT1 } \\
\text { HEK293-OAT1 } \\
\text { MDCK-OAT1 }\end{array}$ & $\begin{array}{l}\text { p-Aminohippurate }(31) \\
\text { Cidofovir (31) } \\
\text { Methotrexate (32) }\end{array}$ & Probenecid (33) & $\begin{array}{l}\text { Cidofovir } \\
\text { Cephradine } \\
\text { Ciprofloxacin }\end{array}$ \\
\hline OAT3 (SLC22A8) & $\begin{array}{l}\text { CHO-OAT3 } \\
\text { HEK293-OAT3 } \\
\text { MDCK-OAT3 } \\
\end{array}$ & $\begin{array}{l}\text { Estrone 3-sulfate (31) } \\
\text { Cimetidine (31) } \\
\text { Methotrexate (32) }\end{array}$ & Probenecid (33) & $\begin{array}{l}\text { Cimetidine } \\
\text { Cephradine } \\
\text { Ciprofloxacin }\end{array}$ \\
\hline $\begin{array}{l}\text { OATP1B1 } \\
(S L C O 1 B 1)\end{array}$ & $\begin{array}{l}\text { CHO-OATP1B1* } \\
\text { HEK293-OATP1B1* } \\
\text { MDCK-OATP1B1* }\end{array}$ & $\begin{array}{l}\text { Bromosulfophthalein (34) } \\
\text { Estradiol 17ß-glucuronide (35) } \\
\text { Estrone 3- sulfate (36) } \\
\text { Pitavastatin (36) } \\
\text { Atorvastatin (36) } \\
\text { Pravastatin (36) } \\
\text { Rosuvastatin (30) } \\
\text { Valsartan (37) }\end{array}$ & $\begin{array}{l}\text { Estropipate (38) } \\
\text { Cyclosporin A (39) } \\
\text { Rifampin (40) } \\
\text { Rifamycin SV (40) } \\
\text { Bromosulfophthalein (41) }\end{array}$ & $\begin{array}{l}\text { Rosuvastatin } \\
\text { Atorvastatin } \\
\text { Pitavastatin } \\
\text { Pravastatin }\end{array}$ \\
\hline
\end{tabular}




\begin{tabular}{|c|c|c|c|c|}
\hline $\begin{array}{l}\text { OATP1B3 }^{a} \\
\text { (SLCO1B3) }\end{array}$ & $\begin{array}{l}\text { CHO-OATP1B3* }^{*} \\
\text { HEK293-OATP1B3* }^{*} \\
\text { MDCK-OATP1B3* }^{*}\end{array}$ & $\begin{array}{l}\text { Cholecystokinin octapeptide (36) } \\
\text { Estradiol 17ß-glucuronide (42) } \\
\text { Bromosulfophthalein (36) } \\
\text { Valsartan (36) }\end{array}$ & $\begin{array}{l}\text { Bromosulfophthalein (43) } \\
\text { Ursolic acid (38) } \\
\text { Cyclosporin A (39) } \\
\text { Rifampin (40) } \\
\text { Rifamycin SV (40) }\end{array}$ & Telmisartan \\
\hline $\begin{array}{l}\text { OATP2B1 }{ }^{a} \\
\text { (SLCO2B1) }\end{array}$ & $\begin{array}{l}\text { CHO-OATP2B1* } \\
\text { HEK293-OATP2B1* } \\
\text { MDCK-OATP2B1** }^{*}\end{array}$ & Estrone 3-sulfate (36) & Bromosulfophthalein (43) & Rosuvastatin \\
\hline MATE-1 (SLC47A1) & $\begin{array}{l}\text { CHO-MATE1 } \\
\text { HEK293-MATE1 }\end{array}$ & $\begin{array}{l}\text { Tetraethyl ammonium (44) } \\
\text { 1-methyl-4-phenylpyridinium (44) } \\
\text { Metformin (44) }\end{array}$ & $\begin{array}{l}\text { Quinidine (44) } \\
\text { Verapamil (44) } \\
\text { Cimetidine (45) } \\
\text { Pyrimethamine (44) }\end{array}$ & Metformin \\
\hline $\begin{array}{l}\text { MATE-2, MATE-2K } \\
\text { (SLC47A2) }\end{array}$ & $\begin{array}{l}\text { CHO-MATE-2K } \\
\text { HEK293-MATE2K }\end{array}$ & $\begin{array}{l}\text { Tetraethyl ammonium (44) } \\
\text { 1-methyl-4-phenylpyridinium (44) } \\
\text { Metformin (44) }\end{array}$ & $\begin{array}{l}\text { Quinidine (44) } \\
\text { Verapamil (44) } \\
\text { Cimetidine (45) } \\
\text { Pyrimethamine (44) }\end{array}$ & Metformin \\
\hline
\end{tabular}

${ }^{a}$ Note effects of multiple binding sites. Probe-dependent $\mathrm{IC}_{50} / \mathrm{K}_{\mathrm{i}}$ values have been described. *Boosting expression by treating cells with butyrate (10 mM, $24 \mathrm{hrs)}$ is needed for several of the commonly used expression systems (46); References listed in this table are located in supplementary material available online. 
Table 3. Commonly Used Equations for Calculation of Kinetic Parameters in Vesicles, Cell Lines, and Hepatocytes.

Equation

$$
\begin{aligned}
v & =\frac{V_{\text {max }}[S]}{K_{m}+[S]}+P_{\text {diff }}[S] \\
K_{i} & =\frac{I C_{50}}{1+\frac{[S]}{K_{m}}}
\end{aligned}
$$$$
P_{\text {app }}=\frac{\text { Volume of receptor chamber }(\mathrm{mL})}{\left[\text { Area of membrane }\left(\mathrm{cm}^{2}\right)\right][\text { Initial concentration }(\mu M)]} * \frac{\Delta \text { in concentration }(\mu M)}{\Delta \text { in time }(s)}
$$$$
C L_{\text {uptake }}=\frac{\text { Accumulati on }_{(T 2)}-\text { Accumulati on }_{(T 1)}}{(\mathrm{T} 2-\mathrm{T} 1) * \text { concentrat ion }_{\text {media }}}
$$$$
\% \text { active_uptake }=100-\frac{\text { Slope_with_inhibitor }}{\text { Slope_without_inhibitor }}
$$$$
\text { BEI }=\frac{\text { Accumulation }_{(S t d, \text { HBSS })}-\text { Accumulation }_{(\mathrm{Ca2}+/ \mathrm{Mg} 2+, \text { Free })}}{\text { Accumulation }_{(\mathrm{Std}, \mathrm{HBSS})}}
$$$$
C L_{\text {bile }, \text { app }}=\frac{\text { Accumulation } \text { (Std, HBSS })^{-} \text {Accumulation }{ }_{(\mathrm{Ca} 2+/ \mathrm{Mg} 2+, \text { Free })}}{A U C_{(\text {medium })}}
$$$$
C L_{\text {bile, int }}=\frac{\text { Accumulati on }(\text { Std, HBSS })-\text { Accumulati on }(\mathrm{Ca2}+/ \mathrm{Mg} 2+, \text { Free })}{A U C_{(\text {cell, estimated })}}
$$

Application

Determination of kinetic parameters to describe saturable active transport and passive diffusion

Conversion of $\mathrm{IC}_{50}$ to absolute inhibition constant for competitive inhibitors

Determination of apparent permeability in Transwell ${ }^{\circledR}$ systems

Determination of uptake clearance in cells or vesicles

Determination of active vs. passive uptake in cells or vesicles

Calculation of in vitro biliary excretion index in $\mathrm{SCH}$

Calculation of apparent in vitro biliary clearance in $\mathrm{SCH}$

Calculation of intrinsic in vitro biliary clearance in $\mathrm{SCH}$
Reference

in Text

Eq. 1

Eq. 2

Eq. 3

Eq. 4

Eq. 5

Eq. 6

Eq. 7

Eq. 8 
$\Delta$ (delta): change over time; Accumulation $\left(T_{2}\right)$ and Accumulation $_{(T 1)}$ represent the cumulative amount of drug in SCH over the period T1 to T2. Accumulation ${ }_{(S t d, H B S S)}$ and Accumulation ${ }_{\left(\mathrm{Ca} 2+/ \mathrm{Mg}_{2+}, \text { free }\right)}$ represent the cumulative amount of compound in $\mathrm{SCH}$ in the presence and absence of $\mathrm{Ca}^{2+} / \mathrm{Mg}^{2+}$, respectively. $\mathrm{Cl}_{\text {bile,app }}$ : apparent biliary clearance from medium to bile; $\mathrm{Cl}_{\text {bile,int }}$ : intrinsic biliary clearance from cell to bile. The area under the curve (AUC) in the medium can be calculated based on the medium concentrations of compound at the beginning and end of the accumulation period, or assumed equivalent to the product of the incubation time and the initial medium concentration. $\mathrm{AUC}_{\text {cell }}$ can be estimated from intracellular concentrations as described in the text. 
Table 4. Applications, strengths and limitations of various in vitro transporter assay systems

\begin{tabular}{|c|c|c|c|}
\hline In Vitro System & Applications & Strengths & Limitations \\
\hline Membrane Vesicles & $\begin{array}{l}\text { Evaluate drug interactions with } \\
\text { efflux transporters (ABC- } \\
\text { transporters) } \\
\text { Determine substrate specificity } \\
\text { and identify inhibitors }\end{array}$ & $\begin{array}{l}\text { - } \quad \text { Good for compound with low } \mathrm{P}_{\text {app }} \\
\text { - } \quad \text { Cytotoxic compounds do not impact } \\
\text { the experimental system } \\
\text { - } \text { High transporter expression levels in } \\
\text { recombinant systems and transporter } \\
\text { expression can be "titrated" in certain } \\
\text { expression systems } \\
\text { - } \quad \text { Large batches can be prepared and } \\
\text { cryopreserved for ready availability } \\
\text { - } \text { Able to be preloaded with a variety of } \\
\text { buffers and substances } \\
\text { - Accurate determination of kinetics as } \\
\text { substrates in incubation buffer have } \\
\text { direct access to active sites }\end{array}$ & $\begin{array}{ll}\text { - } & \text { Not suitable for compounds with high } \\
& \mathrm{P}_{\text {app }} \text {, or high non-specific binding } \\
\text { - } & \text { Relatively high rate of false } \\
\text { - } & \text { negatives for substrate identification } \\
\text { - } & \text { alter transport characteristics } \\
\text { Endogenous transport activity in the } \\
\text { expression system may complicate } \\
\text { data interpretation } \\
\text { Transporter activity varies from batch } \\
\text { to batch } \\
\text { Special equipment is necessary if } \\
\text { prepared in house (ultracentrifuge or } \\
\text { nitrogen cavitation bomb) }\end{array}$ \\
\hline $\begin{array}{l}\text { Recombinant cell } \\
\text { lines expressing } \\
\text { uptake transporters }\end{array}$ & $\begin{array}{l}\text { Evaluate drug interactions with } \\
\text { uptake transporters (OATPs, } \\
\text { OCTs, OATs, NTCP) } \\
\text { Determine substrate specificity } \\
\text { and identify inhibitors }\end{array}$ & $\begin{array}{l}\text { - Allows investigation of the } \\
\text { characteristics of a single transporter } \\
\text { - Stably transfected cell lines can be } \\
\text { passaged for multiple use or } \\
\text { cryopreserved } \\
\text { - Low complexity }\end{array}$ & $\begin{array}{l}\text { Endogenous transporter activity in } \\
\text { host cells may complicate data } \\
\text { interpretation } \\
\text { - Generation and characterization of } \\
\text { stable recombinant cell lines is time } \\
\text { consuming (>1 month) } \\
\text { Transporter expression levels vary } \\
\text { between laboratories }\end{array}$ \\
\hline $\begin{array}{l}\text { Polarized cell } \\
\text { monolayers }\end{array}$ & $\begin{array}{ll}\text { - } & \text { Evaluate drug transport by } \\
\text { efflux transporters } \\
\text { Determine substrate specificity } \\
\text { and identify inhibitors } \\
\text { - } \quad \text { Investigate the interplay } \\
\text { between uptake and efflux } \\
\text { transporters qualitatively } \\
\end{array}$ & $\begin{array}{l}\text { Transport is less influenced by non- } \\
\text { specific binding since only the } \\
\text { compound crossing the cell monolayer } \\
\text { is measured } \\
\text { - Suitable to assess active transport } \\
\text { versus diffusion }\end{array}$ & $\begin{array}{ll}\text { - } & \text { Endogenous transporter activity may } \\
\text { - } & \text { Mamplicate data interpretation } \\
\text { - } & \text { Complicated kinetic studies } \\
\text { - } & \text { Not suitable for compounds with low } \\
\mathrm{P}_{\text {app }} \text { unless uptake transporter is co- } \\
\text { expressed }\end{array}$ \\
\hline $\begin{array}{l}\text { Plated hepatocytes } \\
\text { or hepatocytes in } \\
\text { suspension }\end{array}$ & $\begin{array}{l}\text { Evaluate drug uptake } \\
\text { mediated by hepatic } \\
\text { transporters } \\
\text { - } \quad \text { Identify inhibitors of active } \\
\text { uptake } \\
\text { - Identify transporters involved } \\
\text { in initial uptake of drugs } \\
\end{array}$ & $\begin{array}{l}\text { Expression of various uptake } \\
\text { transporters relatively close to in vivo } \\
\text { Allows assessment of contribution of } \\
\text { multiple hepatic uptake transporters } \\
\text { simultaneously } \\
\text { Cryopreserved or freshly isolated } \\
\text { hepatocytes from the species of }\end{array}$ & $\begin{array}{l}\text { - } \quad \text { Loss of cell polarity } \\
\text { - } \quad \text { No functional activity of canalicular } \\
\text { efflux transporters } \\
\text { - } \quad \text { Rapid loss of metabolic activity in } \\
\text { culture } \\
\text { - } \quad \text { Membrane integrity of suspended }\end{array}$ \\
\hline
\end{tabular}

(c) 2013 American Society for Clinical Pharmacology and Therapeutics. All rights reserved 


\begin{tabular}{|c|c|c|c|}
\hline & & $\begin{array}{l}\text { interest can be used } \\
\text { - Pools of human hepatocytes can be } \\
\text { applied to eliminate inter-individual } \\
\text { variability } \\
\text { - Allows assessment of active uptake } \\
\text { versus diffusion }\end{array}$ & $\begin{array}{l}\text { cryopreserved hepatocytes may be } \\
\text { compromised }\end{array}$ \\
\hline $\begin{array}{l}\text { Sandwich-cultured } \\
\text { hepatocytes }\end{array}$ & $\begin{array}{l}\text { - Evaluate hepatic uptake/efflux } \\
\text { and biliary excretion } \\
\text { - } \text { Identify transporters and rate- } \\
\text { limiting steps involved in } \\
\text { hepatobiliary drug disposition } \\
\text { - Assess potential for drug- } \\
\text { induced cholestasis due to } \\
\text { transporter inhibition } \\
\text { - Investigate the interplay } \\
\text { between uptake and efflux } \\
\text { transporters } \\
\text { - Assess intracellular } \\
\text { concentration, } \mathrm{K}_{\text {puu, and }} \text { and } \\
\text { subcellular distribution of } \\
\text { drugs }\end{array}$ & $\begin{array}{l}\text { - System mimics biliary excretion, and } \\
\text { biliary clearance can be measured } \\
\text { - Holistic system expressing both uptake } \\
\text { and efflux transporters, metabolic } \\
\text { enzymes, and regulatory machinery } \\
\text { - Cryopreserved or freshly isolated } \\
\text { hepatocytes from the species of } \\
\text { interest can be used } \\
\text { - Suitable to identify transporter } \\
\text { inhibitors (both competitive and non- } \\
\text { competitive) and inducers } \\
\text { Demonstrated in vitro-to-in vivo } \\
\text { correlations in preclinical species and } \\
\text { humans }\end{array}$ & $\begin{array}{l}\text { - Requires time in culture for proper } \\
\text { localization of transporters in } \\
\text { appropriate membrane domains } \\
\text { - Less suitable for low clearance } \\
\text { compounds (especially if metabolism } \\
\text { is involved) } \\
\text { - Enzyme/transporter } \\
\text { expression/activity may be } \\
\text { modulated by culture conditions }\end{array}$ \\
\hline
\end{tabular}


Table 5. Flow Diagram: Integration of in vitro and in vivo data to determine the role of transporters in compound absorption, distribution, clearance, and DDIs

\begin{tabular}{|c|c|c|c|c|c|}
\hline & $\begin{array}{l}\text { Scientific } \\
\text { Question }\end{array}$ & $\Rightarrow \begin{array}{c}\text { Observations to Support In } \\
\text { Vitro Transporter } \\
\text { Investigations }\end{array}$ & $\begin{array}{l}\text { In Vitro Tools to Address } \\
\text { Scientific Hypothesis }\end{array}$ & Outcome of In Vitro Experiments & Potential Follow-Up Studies \\
\hline \multirow{4}{*}{ Absorption } & \multirow{2}{*}{$\begin{array}{l}\text { Does active uptake } \\
\text { influence intestinal } \\
\text { absorption? }\end{array}$} & \multirow{2}{*}{$\begin{array}{l}\text { - Less than proportional oral PK } \\
\text { profiles with increasing dose } \\
\text { - High bioavailability despite low } \\
\text { intrinsic permeability } \\
\text { - Disconnect between measured in } \\
\text { vivo absorption or Caco-2 } \\
\text { permeability and physicochemical } \\
\text { parameters/in silico model } \\
\text { predicting poor permeability } \\
\end{array}$} & $\begin{array}{l}\text { - Uptake in models expressing gut } \\
\text { specific uptake transporters (e.g. } \\
\text { PEPT1) }\end{array}$ & $\begin{array}{l}\text { - Mechanistic understanding of individual transporters } \\
\text { - May be possible to understand structure-activity } \\
\text { relationship (SAR) and obtain kinetic parameters for } \\
\text { individual transporters }\end{array}$ & \multirow{4}{*}{$\begin{array}{l}\text { - Preclinical in vivo and ex-vivo studies (e.g. } \\
\text { regional absorption models, IV/PO studies } \\
\text { in transporter knockout mice/rats, portal } \\
\text { vein cannulated studies) } \\
\text { - Modeling software (using kinetic } \\
\text { parameters, transporter abundance) to } \\
\text { estimate clinical impact of active } \\
\text { uptake/efflux on bioavailability }\end{array}$} \\
\hline & & & $\begin{array}{l}\text { - Caco-2 cells (Papp A-B } \pm \\
\text { inhibitors) }\end{array}$ & $\begin{array}{l}\text { - Explore potential impact of multiple transporters on } \\
\text { oral absorption } \\
\text { - Derive intrinsic passive permeability }\end{array}$ & \\
\hline & \multirow{2}{*}{$\begin{array}{l}\text { Does apical efflux } \\
\text { limit intestinal } \\
\text { absorption? }\end{array}$} & \multirow{2}{*}{$\begin{array}{l}\text { - Greater than proportional oral PK } \\
\text { with increasing dose. } \\
\text { - Low oral bioavailability despite } \\
\text { high solubility and permeability }\end{array}$} & $\begin{array}{l}\text { - Bi-directional efflux in single } \\
\text { transfected polarized cell } \\
\text { monolayers (e.g. MDR1 P-gp, } \\
\text { BCRP, MRP2) }\end{array}$ & $\begin{array}{l}\text { - Mechanistic understanding of individual transporters } \\
\text { - May be possible to understand SAR and generate } \\
\text { kinetic parameters for individual transporters }\end{array}$ & \\
\hline & & & $\begin{array}{l}\text { - Caco-2 Papp A-B with inhibitors or } \\
\text { bi-directional efflux studies }\end{array}$ & $\begin{array}{l}\text { Explore potential impact of multiple transporters on } \\
\text { oral absorption and derive intrinsic passive } \\
\text { permeability }\end{array}$ & \\
\hline \multirow{4}{*}{$\begin{array}{l}\text { Distribution } \\
\quad \text { and } \\
\text { Clearance }\end{array}$} & $\begin{array}{l}\text { Is intestinal apical } \\
\text { secretion a possible } \\
\text { clearance pathway? }\end{array}$ & $\begin{array}{l}\text { - Presence of compound in feces } \\
\text { following an IV dose in bile duct } \\
\text { cannulated animals }\end{array}$ & $\begin{array}{l}\text { - Bi-directional efflux in single } \\
\text { transfected polarized cell } \\
\text { monolayers (e.g- MDR1 P-gp, } \\
\text { BCRP) or Caco-2 cell monolayers }\end{array}$ & $\begin{array}{l}\text { - Identification of individual transporters } \\
\text { - May be able to gain mechanistic insight, understand } \\
\text { SAR and generate kinetic parameters for individual } \\
\text { transporters }\end{array}$ & $\begin{array}{l}\text { - Preclinical in vivo and ex-vivo studies (e.g. } \\
\text { regional absorption models, IV studies in } \\
\text { transporter knockout mice/rats, portal vein } \\
\text { cannulated studies, ADME studies with } \\
\text { radiolabeled compound) } \\
\text { - Clinical studies with isolated GI segment } \\
\text { and fluid collection (46) }\end{array}$ \\
\hline & $\begin{array}{l}\text { Does active hepatic } \\
\text { uptake influence the } \\
\text { distribution of } \\
\text { compound to the } \\
\text { liver or contribute to } \\
\text { systemic clearance? }\end{array}$ & $\begin{array}{l}\text { - Under-prediction of in vivo intrinsic } \\
\text { clearance (Clint) from in vitro } \\
\text { metabolic clearance } \\
\text { - High unbound liver: plasma ratios; } \\
\text { can be important to understand } \\
\text { when liver is the target for efficacy } \\
\text { or if there is evidence of liver } \\
\text { specific toxicity }\end{array}$ & $\begin{array}{l}\text { - Initial uptake in suspended or SCH } \\
\text { hepatocytes; test whether } \\
\text { transport is saturable, and study } \\
\text { effect of inhibitors } \\
\text { - Uptake in single transfected cells } \\
\text { with specific transporters (e.g. } \\
\text { OATP1B1, OATP1B3, OATP2B1, } \\
\text { OCT1, NTCP) }\end{array}$ & $\begin{array}{l}\text { - Determine whether active uptake is significant. May } \\
\text { be able to use selective inhibitors to separate role of } \\
\text { individual transporters and generate kinetic } \\
\text { parameters for individual transporters }\end{array}$ & $\begin{array}{l}\text { - IV studies determining liver and plasma } \\
\text { exposure in wild-type and/or transporter } \\
\text { knockout animals } \\
\text { - Relative activity or expression factor } \\
\text { approaches to determine relative } \\
\text { contribution of individual transporters to } \\
\text { uptake (47) }\end{array}$ \\
\hline & \multirow{2}{*}{$\begin{array}{l}\text { Does transporter- } \\
\text { mediated biliary } \\
\text { excretion contribute } \\
\text { to systemic } \\
\text { clearance? }\end{array}$} & \multirow{2}{*}{$\begin{array}{l}\text { - Elimination of parent drug in feces } \\
\text { after IV dose } \\
\text { - Under-prediction of Clin vivo from in } \\
\text { vitro metabolic clearance assays in } \\
\text { microsomes/hepatocytes }\end{array}$} & $\begin{array}{l}\text { - Determine } \mathrm{Cl}_{\text {biliary }} \text { and biliary } \\
\text { excretion index (BEI) in sandwich- } \\
\text { cultured hepatocytes }\end{array}$ & $\begin{array}{l}\text { - Determine whether biliary secretion is important for } \\
\text { parent compound and/or metabolites } \\
\text { - Consider use of selective inhibitors to assess role of } \\
\text { individual transporters }\end{array}$ & \multirow{2}{*}{$\begin{array}{l}\text { - Pre-clinical in vivo studies with bile duct } \\
\text { cannulated rat or knockout mouse/rat } \\
\text { transporter studies } \\
\text { - Use in vitro data as input for PBPK-based } \\
\text { prediction models } \\
\text { - Clinical studies using CHOL-ect catheter or } \\
\text { Loc--IGut with isolated GI segment and fluid } \\
\text { collection (46) }\end{array}$} \\
\hline & & & $\begin{array}{l}\text { - Transport studies in MRP2, BCRP, } \\
\text { BSEP, MATE, and MDR1 P-gp } \\
\text { polarized cell monolayers } \\
\text { - Transport in membrane vesicles } \\
\end{array}$ & $\begin{array}{l}\text { - Identification of individual transporters } \\
\text { - May be able to gain mechanistic insight, understand } \\
\text { SAR, and generate kinetic parameters }\end{array}$ & \\
\hline
\end{tabular}

(c) 2013 American Society for Clinical Pharmacology and Therapeutics. All rights reserved 


\begin{tabular}{|c|c|c|c|c|c|}
\hline \multirow{3}{*}{$\begin{array}{l}\text { Distribution } \\
\quad \text { and } \\
\text { Clearance }\end{array}$} & $\begin{array}{l}\text { Is active renal } \\
\text { secretion } \\
\text { contributing to } \\
\text { systemic clearance? }\end{array}$ & $\begin{array}{l}\text { Pre-clinical in vivo renal } \\
\text { clearance }>\text { fu } x \text { GFR }\end{array}$ & $\begin{array}{l}\text { - Uptake in single transfected cells } \\
\text { (e.g. OAT1, OAT3, OCT2) } \\
\text { - Transwell studies with double } \\
\text { transfected cells expressing relevant } \\
\text { uptake and efflux transporters (e,g, } \\
\text { OATPs, MRP2, OAT4, BCRP, MATEs, } \\
\text { and MDR1 P-gp) } \\
\text { - Transport in membrane vesicles }\end{array}$ & $\begin{array}{l}\text { - Mechanistic understanding of individual } \\
\text { transporters } \\
\text { - May be able to understand SAR and generate } \\
\text { kinetic parameters for individual transporters }\end{array}$ & \multirow[t]{2}{*}{$\begin{array}{l}\text { - Pre-clinical in vivo studies in transporter } \\
\text { knockout mice or rats } \\
\text { - Correlation to renal Clin vivo data to support } \\
\text { renal elimination hypothesis }\end{array}$} \\
\hline & $\begin{array}{l}\text { Is there evidence } \\
\text { for active renal re- } \\
\text { absorption? }\end{array}$ & $\begin{array}{l}\text { - Pre-clinical in vivo renal clearance } \\
<\text { fu x GFR. }\end{array}$ & $\begin{array}{l}\text { - Uptake in single transfected cell } \\
\text { lines (e.g. PEPT1/2, OAT4, URAT1) }\end{array}$ & $\begin{array}{l}\text { - Mechanistic understanding of individual } \\
\text { transporters }\end{array}$ & \\
\hline & $\begin{array}{l}\text { Is active efflux } \\
\text { preventing a } \\
\text { compound from } \\
\text { crossing the blood } \\
\text { brain barrier? }\end{array}$ & $\begin{array}{l}\text { - Lack of pharmacological activity } \\
\text { when compounds potent against a } \\
\text { CNS target are administered in vivo } \\
\text { - Low unbound brain:plasma ratio }\end{array}$ & $\begin{array}{l}\text { - Measure transport in transfected } \\
\text { cell monolayers (e.g. MDR1 P-gp, } \\
\text { BCRP) }\end{array}$ & $\begin{array}{l}\text { - Mechanistic understanding of individual } \\
\text { transporters }\end{array}$ & $\begin{array}{l}\text { - Measure efficacy and/or brain:plasma ratios } \\
\text { in P-gp (Mdr1a/b), Bcrp or triple (Mdr1a/b, } \\
\text { Bcrp) knockout mice or rats }\end{array}$ \\
\hline \multirow{4}{*}{$\begin{array}{c}\text { Drug } \\
\text { Interactions }\end{array}$} & $\begin{array}{l}\text { Is compound a } \\
\text { potential } \\
\text { "perpetrator" of a } \\
\text { transporter- } \\
\text { mediated drug } \\
\text { interaction? }\end{array}$ & $\begin{array}{l}\text { - Co-administer drug with known } \\
\text { transporter substrates with a } \\
\text { narrow therapeutic index } \\
\text { - History of DDI from compounds } \\
\text { within the same chemical class }\end{array}$ & $\begin{array}{l}\text { - Inhibition studies in transfected cells } \\
\text { or vesicles }\end{array}$ & $\begin{array}{l}\text { - Inhibition of key transporters involved in the } \\
\text { disposition of known administered co- } \\
\text { medications } \\
\left.\text { - Generation of kinetic parameters (e.g. } \mathrm{IC}_{50}, \mathrm{~K}_{\mathrm{i}}\right)\end{array}$ & $\begin{array}{l}\text { - Dynamic modeling or static calculation (e.g. } R \text { - } \\
\left.\text { value, }\left[\mathrm{I}_{1}\right] / \mathrm{C}_{50},\left[\mathrm{l}_{1}\right] / \mathrm{IC}_{50}\right) \text { measurements using } \\
\text { in vitro kinetic parameters to estimate DDI risk } \\
\text { - For OCT2/MATE inhibitors, clinical elevations } \\
\text { in serum creatinine but not cystatin C may } \\
\text { serve as a biomarker for DDI potential (48) }\end{array}$ \\
\hline & $\begin{array}{l}\text { Is compound a } \\
\text { potential "victim" of } \\
\text { a transporter- } \\
\text { mediated drug } \\
\text { interaction? }\end{array}$ & $\begin{array}{l}\text { - Results from absorption, } \\
\text { distribution, or clearance data in } \\
\text { this table } \\
\text { - History of transporter involvement } \\
\text { in drug disposition within the same } \\
\text { chemical class }\end{array}$ & $\begin{array}{l}\text { - Use in vitro tools from other } \\
\text { questions in this table (e.g. } \\
\text { absorption, clearance and } \\
\text { distribution) to determine whether } \\
\text { the compound is a substrate } \\
\text { - Follow-up inhibition studies with } \\
\text { appropriate inhibitors }\end{array}$ & $\begin{array}{l}\text { - Identification of transporters that may be } \\
\text { involved in compound absorption, distribution } \\
\text { and clearance } \\
\text { - May generate kinetic parameters for individual } \\
\text { transporters }\end{array}$ & $\begin{array}{l}\text { - Dynamic modeling to determine clinical } \\
\text { relevance (e.g. }>25 \% \text { of parent compound } \\
\text { excreted in bile or urine) } \\
\text { - Integration of data to understand alternate } \\
\text { clearance pathways/fraction transported }\end{array}$ \\
\hline & $\begin{array}{l}\text { Can inhibition of } \\
\text { transporters } \\
\text { increase the risk for } \\
\text { hyper- } \\
\text { bilirubinemia?* }\end{array}$ & $\begin{array}{l}\text { - Clinical hyperbilirubinemia } \\
\text { - Preclinical toxicology results } \\
\text { showing increased (conjugated) } \\
\text { bilirubin levels }\end{array}$ & $\begin{array}{l}\text { - OATP1B1, OATP1B3, OATP2B1 and } \\
\text { MRP2 inhibition studies in } \\
\text { transfected cell lines and vesicles } \\
\text { - Inhibition of bilirubin transport in } \\
\text { sandwich-cultured hepatocytes }\end{array}$ & $\begin{array}{l}\text { - Identification of transporter(s) that may } \\
\text { contribute to altered bilirubin disposition } \\
\left.\text { - Generation of kinetic parameters (e.g. I I } \mathrm{C}_{50}, \mathrm{Ki}\right)\end{array}$ & $\begin{array}{l}\text { - Clinical measurement of indirect } \\
\text { (unconjugated) and direct (conjugated) } \\
\text { bilirubin may help determine whether effects } \\
\text { are on uptake, efflux, or both } \\
\text { - UGT1A1 inhibition studies may increase } \\
\text { understanding of unconjugated bilirubin } \\
\text { elevations }\end{array}$ \\
\hline & $\begin{array}{l}\text { Can inhibition of } \\
\text { transporters } \\
\text { increase the risk for } \\
\text { drug-induced } \\
\text { cholestasis?* }\end{array}$ & $\begin{array}{l}\text { - Previous history of clinical } \\
\text { cholestasis for compounds within } \\
\text { the same chemical class } \\
\text { - Preclinical toxicology results } \\
\text { showing elevated serum bile acids }\end{array}$ & $\begin{array}{l}\text { - BSEP inhibition in vesicles } \\
\text { - Inhibition of bile acid transport in } \\
\text { sandwich-cultured hepatocytes }\end{array}$ & $\begin{array}{l}\text { - Potential for compound to alter bile acid } \\
\text { disposition in the liver }\end{array}$ & $\begin{array}{l}\text { - Inhibition of NTCP and OATP to rule out bile } \\
\text { acid uptake inhibition } \\
\text { - Inhibition of other hepatic bile acid } \\
\text { transporters }\end{array}$ \\
\hline
\end{tabular}

(c) 2013 American Society for Clinical Pharmacology and Therapeutics. All rights reserved 
*Several mechanisms may contribute to drug-induced cholestasis and conjugated hyperbilirubinemia. Inhibition of transporters alone does not always result in clinical symptoms. Additional experiments and clinical monitoring should be conducted to assess the potential for occurrence of these adverse events. References listed in this table are located in supplementary material available online. 


\section{Figure 1}

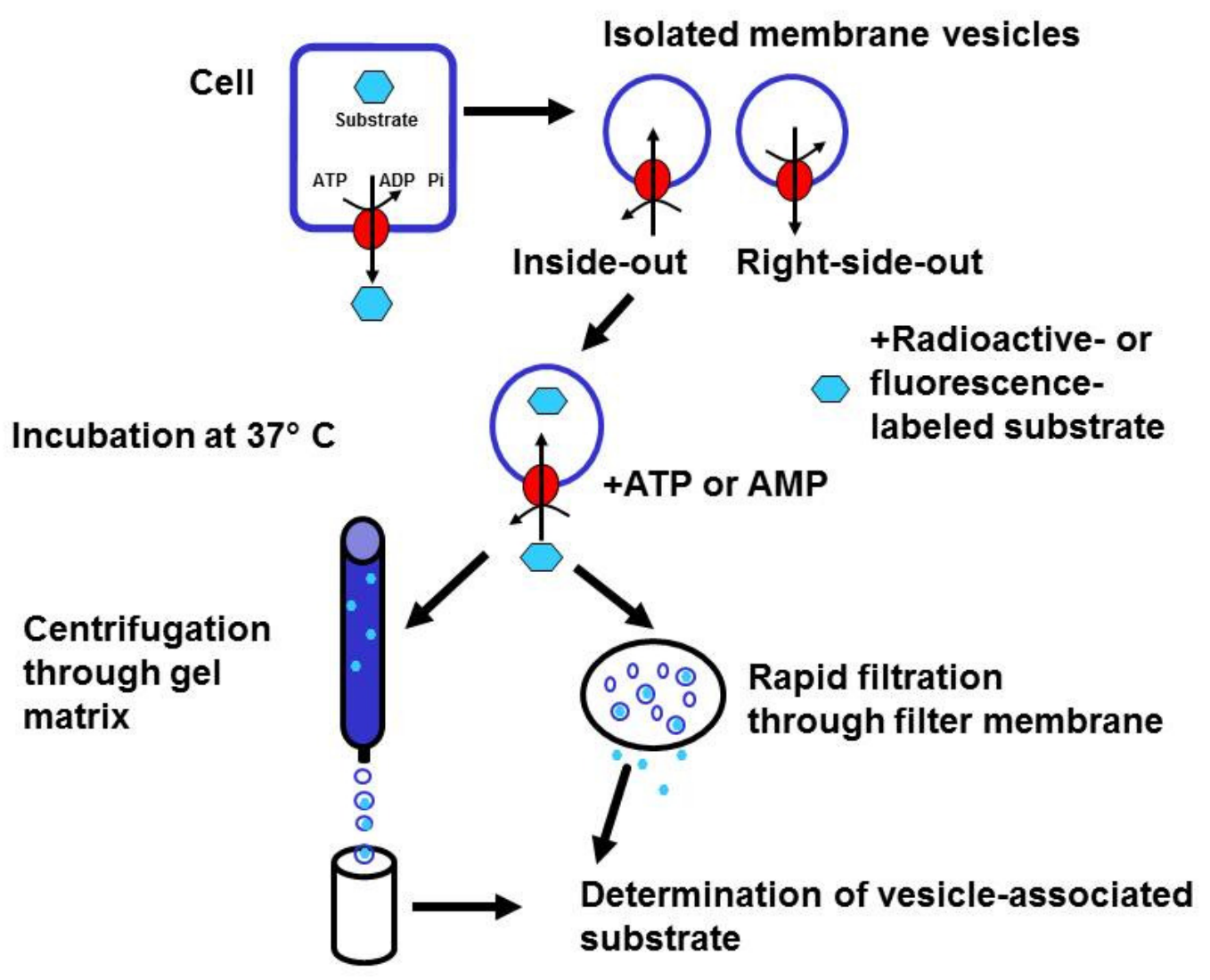


Figure 2

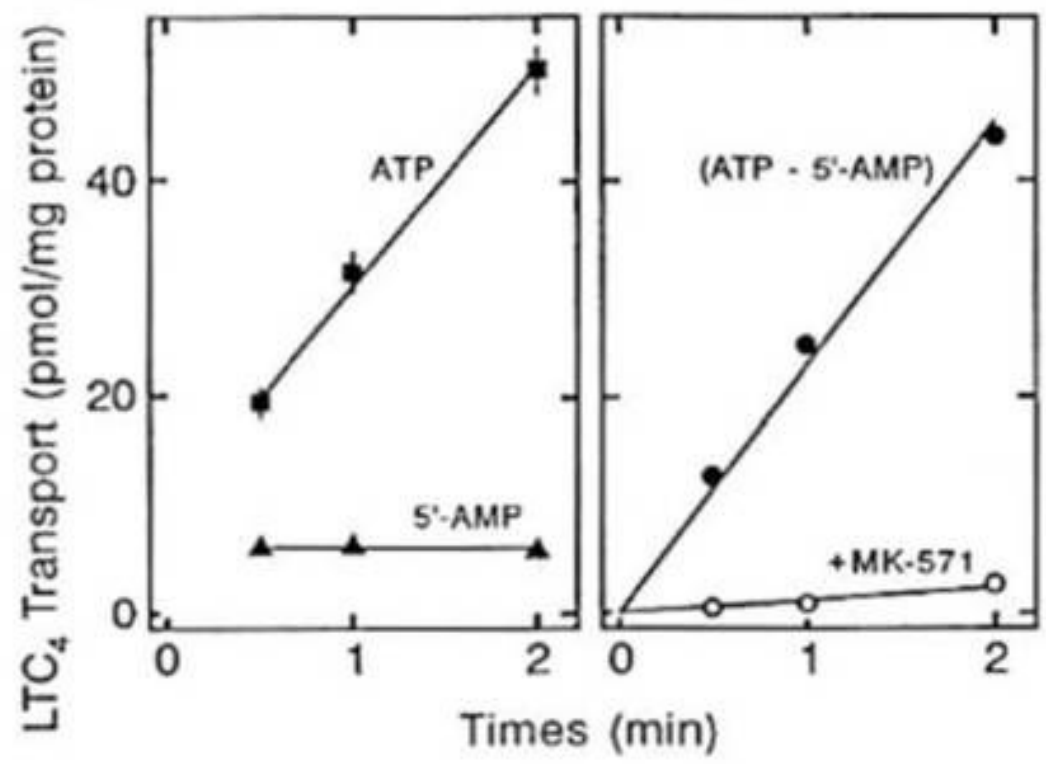

(C) 2013 American Society for Clinical Pharmacology and Therapeutics. All rights reserved 


\section{Figure 3}
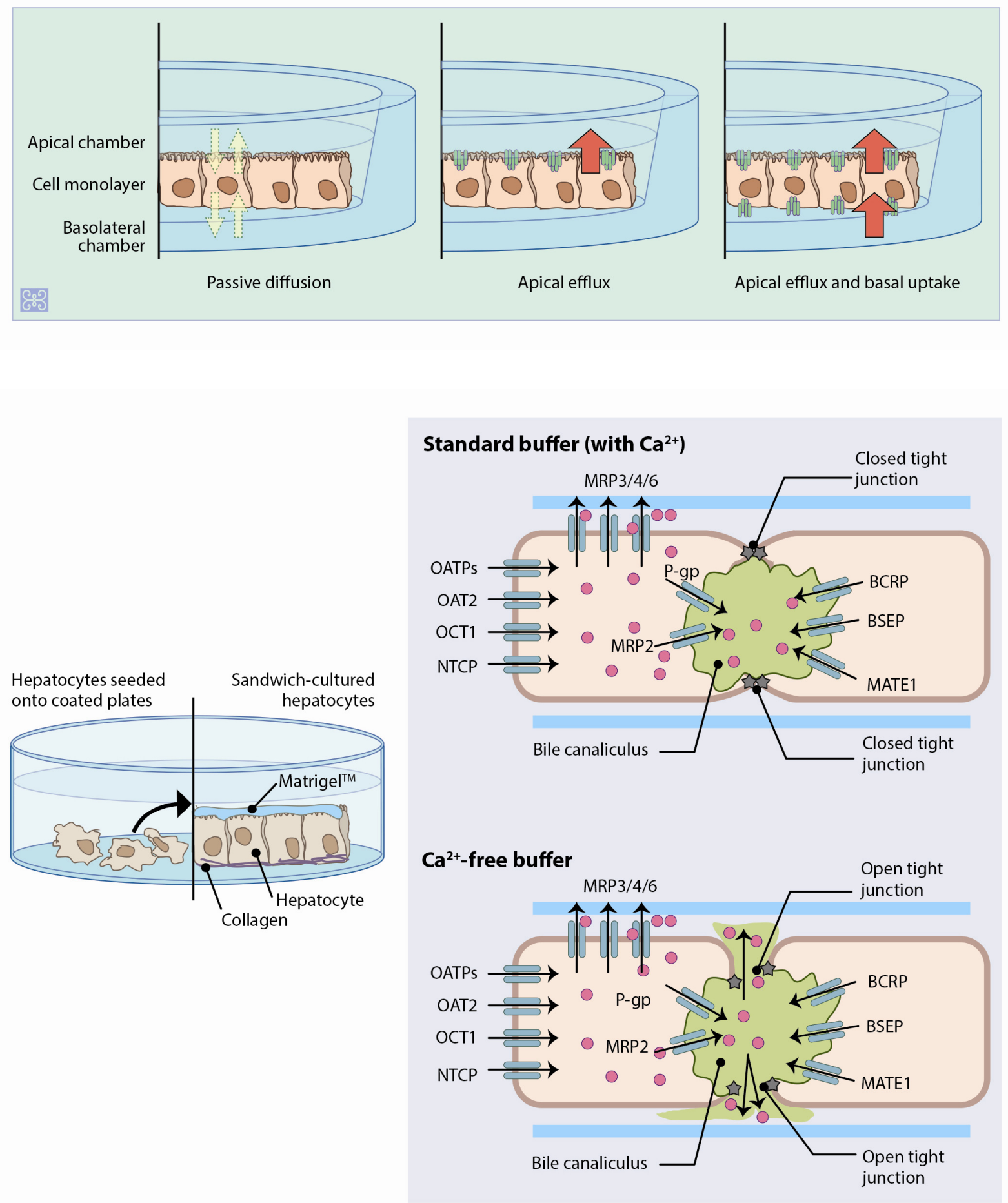